\title{
Usnic Acid and Usnea barbata (L.) F.H. Wigg. Dry Extracts Promote Apoptosis and DNA Damage in Human Blood Cells through Enhancing ROS Levels
}

\author{
Violeta Popovici ${ }^{1}$ (D), Elena Matei ${ }^{2, *}$, Georgeta Camelia Cozaru ${ }^{2,3}$, Mariana Aschie ${ }^{2,3}$, Laura Bucur 4,*, \\ Dan Rambu ${ }^{5}$, Teodor Costache ${ }^{5}$ D , Iulia Elena Cucolea ${ }^{5}$, Gabriela Vochita ${ }^{6}$, Daniela Gherghel ${ }^{6}$, \\ Aureliana Caraiane ${ }^{7}$ and Victoria Badea ${ }^{1}$
}

Citation: Popovici, V.; Matei, E.; Cozaru, G.C.; Aschie, M.; Bucur, L.; Rambu, D.; Costache, T.; Cucolea, I.E.; Vochita, G.; Gherghel, D.; et al. Usnic Acid and Usnea barbata (L.) F.H. Wigg. Dry Extracts Promote Apoptosis and DNA Damage in Human Blood Cells through Enhancing ROS Levels. Antioxidants 2021, 10, 1171. https:// doi.org/10.3390/antiox10081171

Academic Editors: Maria A. Livrea and Mario Allegra

Received: 2 July 2021

Accepted: 19 July 2021

Published: 23 July 2021

Publisher's Note: MDPI stays neutral with regard to jurisdictional claims in published maps and institutional affiliations.

Copyright: (c) 2021 by the authors. Licensee MDPI, Basel, Switzerland. This article is an open access article distributed under the terms and conditions of the Creative Commons Attribution (CC BY) license (https:/ / creativecommons.org/licenses/by/ $4.0 /)$.
1 Department of Microbiology and Immunology, Faculty of Dental Medicine, Ovidius University of Constanta, 7 Ilarie Voronca Street, 900684 Constanta, Romania; violeta.popovici@365.univ-ovidius.ro (V.P.); victoria.badea@365.univ-ovidius.ro (V.B.)

2 Center for Research and Development of the Morphological and Genetic Studies of Malignant Pathology, Ovidius University of Constanta, CEDMOG, 145 Tomis Blvd., 900591 Constanta, Romania; drcozaru@yahoo.com (G.C.C.); aschiemariana@yahoo.com (M.A.)

3 Clinical Service of Pathology, Sf. Apostol Andrei Emergency County Hospital, 145 Tomis Blvd., 900591 Constanta, Romania

4 Department of Pharmacognosy, Faculty of Pharmacy, Ovidius University of Constanta, 6 Capitan Al. Serbanescu Street, 900001 Constanta, Romania

5 Research Center for Instrumental Analysis SCIENT, 1E Petre Ispirescu Street, Tancabesti, 077167 Ilfov, Romania; dan.rambu@scient.ro (D.R.); teodor.costache@scient.ro (T.C.); iulia.cucolea@scient.ro (I.E.C.)

6 NIRDBS, Institute of Biological Research Iasi, 47 Lascar Catargi Street, 700107 Iasi, Romania; gabriela.vochita@icbiasi.ro (G.V.); daniela.gherghel@icbiasi.ro (D.G.)

7 Department of Oral Rehabilitation, Faculty of Dental Medicine, Ovidius University of Constanta, 7 Ilarie Voronca Street, 900684 Constanta, Romania; aureliana.caraiane@365.univ-ovidius.ro

* Correspondence: sogorescuelena@gmail.com (E.M.); laurabucur@univ-ovidius.ro (L.B.); Tel.: +40-72-394-3559 (E.M.); +40-72-152-8446 (L.B.)

Abstract: Nowadays, numerous biomedical studies performed on natural compounds and plant extracts aim to obtain highly selective pharmacological activities without unwanted toxic effects. In the big world of medicinal plants, Usnea barbata (L) F.H. Wigg (U. barbata) and usnic acid (UA) are well-known for their therapeutical properties. One of the most studied properties is their cytotoxicity on various tumor cells. This work aims to evaluate their cytotoxic potential on normal blood cells. Three dry U. barbata extracts in various solvents: ethyl acetate (UBEA), acetone (UBA), and ethanol (UBE) were prepared. From UBEA we isolated usnic acid with high purity by semipreparative chromatography. Then, UA, UBA, and UBE dissolved in 1\% dimethyl sulfoxide (DMSO) and diluted in four concentrations were tested for their toxicity on human blood cells. The blood samples were collected from a healthy non-smoker donor; the obtained blood cell cultures were treated with the tested samples. After $24 \mathrm{~h}$, the cytotoxic effect was analyzed through the mechanisms that can cause cell death: early and late apoptosis, caspase 3/7 activity, nuclear apoptosis, autophagy, reactive oxygen species (ROS) level and DNA damage. Generally, the cytotoxic effect was directly proportional to the increase of concentrations, usnic acid inducing the most significant response. At high concentrations, usnic acid and $U$. barbata extracts induced apoptosis and DNA damage in human blood cells, increasing ROS levels. Our study reveals the importance of prior natural products toxicity evaluation on normal cells to anticipate their limits and benefits as potential anticancer drugs.

Keywords: Usnea barbata; usnic acid; secondary metabolites; blood cells; DNA damage; apoptosis; cytotoxic effect; oxidative stress 


\section{Introduction}

Natural products have a significant role in modern drug development, especially as antitumor agents [1]. Since discovering that plant secondary metabolites have been elaborated for adaptive reasons [2] within living systems [3], they are often understood as exhibiting more drug-likeness and biological friendliness [4] than totally synthetic molecules [5]. Complex biomedical studies performed on isolated natural compounds and plant extracts aim to obtain high therapeutic activity to treat various diseases without unwanted effects [6]. Especially in oncological pathology, in vitro and in vivo studies have as their principal objective a selective cytotoxic action against tumor cells without affecting the normal ones [7].

In the big world of medicinal plants, lichens are symbiotic organisms [8] between a fungus and microalgae/cyanobacteria [9], known since ancient times for their biological effects [10]. As an important representative of this plant group, Usnea barbata (L) F.H. Wigg (U. barbata) is a fruticose thalli lichen with interesting therapeutic properties [11]; this species has been used for thousands of years in traditional medicine worldwide to treat various diseases [12]. The wide range of bio-activities (antioxidant [13], antimicrobial [14], anti-inflammatory [15], anticancer [16], cytotoxic [17], pro-oxidant [18]) is due to the content of active secondary metabolites [19] synthesized by the mycobiont (lichen-forming fungus) [20]. The phytochemical profile of $U$. barbata is already known. The metabolomics of this species belongs to different classes of chemical compounds: depsides (barbatic acid, methyl-8-hydroxy-4-O-demethylbarbatate, baeomycesic acid, 8-hydroxybarbatic acid), depsidones (connorstictic acid, fumarprotocetraric acid, hypoconstictic acid, lobaric acid), lipids (polyhydroxylated lipids), and dibenzofurans (usnic acid, placodiolic acid) [21]. Of all these lichen secondary metabolites, usnic acid [22] is by far the best known [23] and responsible for most bio-activities [24] of the $U$. barbata and, at the same time, of all lichens of the Usnea genus [25].

Usnic acid is an extensively studied lichen metabolite with controversial [26,27] results related to its benefits in relationship with the extraction method and the lichen species [28]. It was used to induce human weight loss [29], although unwanted hepatotoxic effects were also triggered [30]. In addition, UA highlights antimicrobial [31], insecticidal [32], anticholinergic [33], antioxidant [34], pro-oxidant [35], antigenotoxic [36], genotoxic [37], teratogenic [38], anti-inflammatory [39], analgesic and antipyretic [40], mutagenic and carcinogenic [41], anticancer [42], and cytotoxic [43] activities. Numerous researchers have shown the pharmacological actions of usnic acid and Usnea sp. extracts, especially cytotoxic activity, on different types of tumor cells [44].

The most important event resulting from the cytotoxic activity is cell death, which consists of morphological alterations [45]. Hence, the highly described mechanism in usnic acid and Usnea sp. anticancer activity is apoptosis [46]. This programmed cell death (PCD) is associated with DNA fragmentation and recognized by morphological characteristics as well as cytoplasmic condensation, nuclear pyknosis, chromatin condensation, cell rounding, membrane blebbing, and cytoskeletal collapse. In addition, membrane-bound apoptotic bodies are formed; macrophages rapidly digest them without activating the immune response [47]. In apoptosis, biochemical events through two distinct pathways (extrinsic and intrinsic) are correlated with these morphological changes [48]. Thus, the common extrinsic pathway (receptor-mediated) begins with receptor binding and activation of the initiator caspase-8. The following step is caspase-3 activation by caspase- 8 or Bid-a B-cell lymphoma 2 (Bcl-2) pro-apoptotic protein-cleavage. Bid splitting brings mitochondrial cytochrome $c$ leakage and apoptosomes formation. The intrinsic (mitochondrial) apoptotic pathway consists of cytochrome $c$ release by Bcl-2 pro-apoptotic proteins action. Next, cytochrome $c$ interacts with Apaf-1, dATP, and procaspase 9, generating apoptosomes. As a result, caspase- 9 and -3 activation follows in both pathways. Moreover, various cell apoptosis can occur through common or specific biochemical processes [48,49]; for instance, a considerable diversity of molecular mechanisms involved in this PCD was highlighted in the different blood cells types. Thereby, nucleus-free platelets exhibit 
increasing mitochondrial functions in ATP synthesis, energy metabolism, cells survival and apoptosis activation [49]. Thereby, the major apoptotic pathway is the intrinsic one, with overexpression of Bcl-2 pro-apoptotic proteins, depolarization of the mitochondrial membrane potential, and cytochrome $c$ release [50]. The extrinsic apoptotic pathway is initiated by tumor necrosis factor (TNF) death ligands binding to platelets surface TNF receptors. Finally, caspase- 3 activation induces phosphatidylserine (PS) exposure and platelet microparticles (PMPs) formation, generating thrombotic phenomena [51].

Otherwise, mammalian erythrocytes (red blood cells, RBCs) have been considered unable to undergo apoptosis because they contain neither mitochondria nor nucleus. However, RBCs contain procaspase- 3 and procaspase- 8 levels comparable with those found in Jurkat cells [52]. They can express caspase-3 and caspase-8 [53], but they do not display other elements of the apoptotic machinery, such as Apaf-1, cytochrome $c$, and caspases-2, -6, -7 and -9 [54]. Klatt et al. (2018) reported that significant receptors belonging to the tumor necrosis factors (TNF) family (CD95 [55] and Fas [56]) signaling in RBCs are known to induce a particular type of programmed cell death, similar to the apoptotic death of nucleated cells named eryptosis [57], by caspase-3 activation, leading to cell shrinkage and cell membrane scrambling [58] with PS externalization [59]. The major trigger of eryptosis is the increase of cytosolic $\mathrm{Ca}^{2+}$ activity resulting from $\mathrm{Ca}^{2+}$ entry through $\mathrm{Ca}^{2+}$-permeable unselective cation channels (permeable to both $\mathrm{Na}^{+}$and $\mathrm{Ca}^{2+}$ ) [60]. Instead, $\mathrm{Ca}^{2+}$ entry and $\mathrm{Ca}^{2+}$-dependent RBCs membrane scrambling do not require caspases activation $[61,62]$.

Leucocytes (white blood cells, WBCs) apoptosis displays morphological features like in other nucleated cells; however, this PCD involves distinct molecular mechanisms in various WBCs types. For instance, the extrinsic apoptosis pathway in monocytes is modulated by CD95, Fas, and TNF-cell surface apoptosis-triggering receptors (TRAIL-R1 and TRAILR2); it recruits cytoplasmic adaptor proteins, forming a death-inducing signaling complex (DISC) [63]. Moreover, various apoptotic agents (including commonly used chemotherapeutic drugs) induce the release of cytochrome $c$ and the second mitochondria-derived activator of caspase/direct inhibitor of apoptosis-binding protein (Smac/DIABLO) in the intrinsic pathway; both proteins determine caspase-3 activation [63] in this WBCs type.

Therefore, we aim to explore cell death mechanisms in our study, analyzing the cytotoxic effects of usnic acid and $U$. barbata extracts. Usnic acid can be obtained by organic synthesis, but it can be isolated from various lichens extracts [64]. A previous report has described UA extraction from $U$. barbata acetone extract [65]; however, this present study proposes to show usnic acid isolation from UBEA. Because relatively few studies are focused exclusively on proving their effects on normal cells [66], the cytotoxicity of isolated UA and $U$. barbata dry extracts (UBA and UBE) on human blood cells cultures was evaluated in our work. Consequently, our study aims to investigate cell death mechanisms, analyzing cellular apoptosis, caspase 3/7 activity, nuclear shrinkage, lysosomal activity, ROS levels, cell cycle, and DNA synthesis by flow cytometry techniques. Finally, we suggest a relationship overview between UA, UBA, UBE concentrations, and cytotoxic activity on human blood cells cultures.

\section{Materials and Methods}

\subsection{Lichen Samples and Usnic Acid Isolation}

U. barbata was harvested from the Călimani Mountains (900 m altitude, Suceava County, Romania). Three dry extracts were obtained in different solvents: ethyl acetate (Chemical Company S.A., Iasi, Romania), acetone and ethanol (Chimreactiv SRL Bucharest, Romania) using a method described in detail in our previous study [13]. The dry extract in ethyl acetate was used only for usnic acid isolation. Further, in vitro studies were performed with isolated UA, UBA and UBE dissolved in 1\% dimethyl sulfoxide (DMSO). Therefore, we prepared sample solutions with different concentrations: UA of 25, 50, 75, $125 \mu \mathrm{g} / \mathrm{mL}$ and both UBA and UBE of 75, 125, 250, $500 \mu \mathrm{g} / \mathrm{mL}$. 


\subsubsection{Usnic Acid Isolation by Semi-Preparative Chromatography}

This process consists of usnic acid extraction by ultra-high performance liquid chromatography (UHPLC) with photodiode array detector (PDA), followed by collecting the separated fraction. A semi-preparative technique was adapted by our UHPLC analytical method previously validated [13]. The PerkinElmer ${ }^{\circledR}$ Flexar ${ }^{\circledR}$ FX-15 UHPLC system was equipped with a Flexar FX PDA-Plus photodiode array detector (PerkinElmer®Waltham, MA, USA) and a Cosmosil 5-C18-AR-2 chromatographic column with a length of $150 \mathrm{~mm}$ and an inner diameter of $20 \mathrm{~mm}$ (producer: Nacalai Tesque, Kyoto, Japan); in addition, a Gilson FC 203B fraction collector (Gilson Co, Middleton, WI, USA) was used. More detailed data can be found in the supplementary material. Working conditions consisted of flow rate $=10 \mathrm{~mL} / \mathrm{min}$, column compartment temperature $=25^{\circ} \mathrm{C}$, injection volume $=400 \mu \mathrm{L}$, analysis time $=18 \mathrm{~min}$. The mobile phase was an isocratic system of methanol/water/glacial acetic acid (80:15:5); the detection was performed at $282 \mathrm{~nm}$ and $254 \mathrm{~nm}$. The samples were prepared at $3 \mathrm{mg} / \mathrm{mL}(282 \mathrm{~nm})$, and $8 \mathrm{mg} / \mathrm{mL}(254 \mathrm{~nm})$. The retention time of the usnic acid is reported around $13 \mathrm{~min}$, at a flow rate of $10 \mathrm{~mL} / \mathrm{min}$.

The usnic acid peak was collected manually between 12.5 and $13.5 \mathrm{~min}$ (on approximately $15 \%$ of its height, preserving the peak purity) after four successive injections $(4 \times 400 \mu \mathrm{L} 8 \mathrm{mg} / \mathrm{mL}$ UBEA in DMSO) at $254 \mathrm{~nm}$. Its identity was confirmed by comparing the retention time of the most significant peak of the sample solution with the reference one [13]. Furthermore, the solution was collected in a previously weighed vial (supplementary material, video sequence S1). The solvent was evaporated under a nitrogen stream and the vial was placed in an oven for $30 \mathrm{~min}$ at $105^{\circ} \mathrm{C}$. After cooling in a desiccator to remove the last solvent traces, a yellow solid matter was obtained. Finally, the isolated usnic acid amount was calculated by subtracting the empty vial mass from the whole mass. The isolated UA was dissolved in 1\% DMSO (Sigma-Aldrich Chemie GmbH, Taufkirchen, Germany) and used for in vitro analyses.

\subsubsection{Determination of the Purity of Isolated Usnic Acid}

The purity of previously isolated UA was determined using the UHPLC-PDA analytical method [13]. First, the sample resulting from drying was weighed and brought to a final concentration of $160 \mu \mathrm{g} / \mathrm{mL}$. Then, three standard usnic acid solutions were prepared simultaneously $(160 \mu \mathrm{g} / \mathrm{mL})$. Finally, all solutions were injected in the same sequence. The purity was calculated according to the following formula:

$$
\begin{gathered}
\mathrm{Ps} \%=\text { As } / \text { Astd } \times \text { Cstd } / \text { Cs } \times 100, \\
\text { Cstd }=\text { Mstd } / \mathrm{d} \times \operatorname{Pstd} \% \times 1000, \\
\text { Cs }=\text { Ms } / \mathrm{d} \times 1000,
\end{gathered}
$$

where, $\mathrm{Ps} \%=$ sample purity $\%$, As $=$ area of the sample, Astd $=$ area of the standard solution, Cstd $=$ standard solution concentration $(\mu \mathrm{g} / \mathrm{mL}) ; \mathrm{Cs}=$ sample solution concentration of the sample solution $(\mu \mathrm{g} / \mathrm{mL})$, Mstd = standard mass weighed $(\mathrm{mg}), \mathrm{d}=$ dilution, $\mathrm{P} \%$ std $=$ standard purity $\%, \mathrm{Ms}=$ sample weighed mass $(\mathrm{mg})$. The previously isolated usnic acid was diluted with DMSO to a $160 \mu \mathrm{g} / \mathrm{mL}$ concentration. Then, this sample solution was injected into the chromatographic system according to the method described in our previous study [13]. The analyzed sequence was represented by the sample solution in DMSO, and three standard solutions of $160 \mu \mathrm{g} / \mathrm{mL}$ (usnic acid in DMSO) considering the average aria. Next, the precision of the area expressed in \% relative standard deviation (RSD) was determined. Following the calculation, the purity value (concerning an external standard) and an RSD value $=0.66 \%$ was obtained. Finally, the identity of isolated usnic acid was certified by the retention time [13] (supplementary material). 


\subsection{In Vitro Analysis of the Biological Effects of UA, UBA, and UBE on Human Blood Cells}

\subsubsection{Human Blood Cell Cultures}

Blood samples from non-smoker healthy donor ( $\mathrm{B} \mathrm{Rh}+$ blood type) were collected into heparin tubes and used throughout the experiment. The heparinized blood $(1.0 \mathrm{~mL})$ in $6.0 \mathrm{~mL}$ of Dulbecco's phosphate buffered saline with $\mathrm{MgCl}_{2}$ and $\mathrm{CaCl}_{2}$ medium (Sigma-Aldrich Chemie $\mathrm{GmbH}$, Taufkirchen, Germany) supplemented with $10 \%$ bovine fetal serum (Sigma-Aldrich, Chemie GmbH, Taufkirchen, Germany), 1\% L-glutamine (Merck, KGaA, Darmstadt, Germany), and antibiotics mix solution $(100 \mu \mathrm{L} / \mathrm{mL}, 10,000 \mathrm{U}$ penicillin, $10 \mathrm{mg}$ streptomycin, $25 \mu \mathrm{g}$ amphotericin B per $1 \mathrm{~mL}$, Sigma-Aldrich, Chemie GmbH, Taufkirchen, Germany) added in 6 wells untreated Nuncleon plates were incubated in a $37^{\circ} \mathrm{C}$ incubator with $5 \% \mathrm{CO}_{2}$. After $72 \mathrm{~h}$ of incubation, blood cell cultures were treated with UA, UBA and UBE dissolved in $1 \%$ DMSO. Human blood samples were treated with final concentrations of $25,50,75$, and $125 \mu \mathrm{g} / \mathrm{mL}$ of UA. Higher concentrations $(75,125,250$, and $500 \mu \mathrm{g} / \mathrm{mL}$ ) of both UBA and UBE were used to treat the human blood cell cultures. In addition, the blood cells were treated with $1 \%$ DMSO as the negative control (solvent control).

\subsubsection{Reagents and Equipment}

Our study analyses used the flow cytometer (Attune, Acoustic focusing cytometer, Applied Biosystems, part of Life Technologies, Bedford, MA, USA). Before blood cells analysis, the flow cytometer was first set by using fluorescent beads (Attune performance tracking beads, labelling and detection, Life Technologies, Europe BV, Bleiswijk, Netherlands), with standard size (four intensity levels of beads population), and the quantity was established by enumerating cells below $1 \mu \mathrm{m}$ [67]; 10,000 cells per sample for each analysis were gated by Forward Scatter (FSC) and Side Scatter (SSC). Flow cytometry data were collected using Attune Cytometric Software v.1.2.5, Applied Biosystems, 2010.

Annexin V-FITC/PI (Bender MedSystems GmbH, Vienna, Austria) was used to observe the apoptotic cells. Activating caspases 3/7 enzymes that determine a series of reactions triggered in response to proapoptotic signals were observed with Red Magic Methodology (MR-DEVD, Caspase-3/7 Assay Kit, Abcam, Shanghai, China). Nuclear apoptosis and lysosomal activity, dual stain with Hoechst 33,342 and acridine orange from MR-DEVD, Caspase-3/7 Assay Kit were analyzed. Total ROS level evaluation was performed using ROS Assay Kit $520 \mathrm{~nm}$ (Life Technologies Europe BV, Bleiswijk, The Netherlands). Propidium iodide (PI) $(1.0 \mathrm{mg} / \mathrm{mL}$, Sigma-Aldrich, Chemie GmbH, Taufkirchen, Germany) and RNase A ( $4 \mathrm{mg} / \mathrm{mL}$, Promega, Madison, USA) were used in cell cycle analysis. Cell proliferation assay was performed using EdU proliferation kit, iFluor 488 (Abcam, Shanghai, China). Negative control was 1\% DMSO (PanBiotech, Aidenbach, Germany).

\subsubsection{Apoptosis Assay}

After $24 \mathrm{~h}$ incubation, the treated blood cells with each tested solution reported to the negative control were double-stained with Annexin V-FITC/PI. Next, blood cells were incubated in flow cytometry tubes with $2 \mu \mathrm{L}$ Annexin V-FITC and $2 \mu \mathrm{L}$ PI $(20 \mu \mathrm{g} / \mathrm{mL})$ for $30 \mathrm{~min}$, at room temperature, in darkness. After incubation, $1 \mathrm{~mL}$ of flow cytometry staining buffer (FCB) (eBioscience ${ }^{\mathrm{TM}}$, Life Technologies Europe BV, Bleiswijk, The Netherlands) was added. Viable cells, early apoptotic cells, late apoptotic cells, and necrotic cells were examined at flow cytometer, using a $488 \mathrm{~nm}$ excitation, green emission for Annexin V-FITC (BL1 channel), and orange emission for PI (BL2 channel).

\subsubsection{Caspase $3 / 7$ Assay}

After $24 \mathrm{~h}$ incubation, $300 \mu \mathrm{L}$ of blood cell culture was transferred to flow cytometry tubes, $20 \mu \mathrm{L}$ of MR-DEVD solution was added and mixed with the cells. Next, $20 \mu \mathrm{L}$ of PI was added. After incubation, was added $1 \mathrm{~mL}$ FCB. The early stages of cell apoptosis by activating caspase $3 / 7$ were analyzed by flow cytometry, using a $488 \mathrm{~nm}$ excitation, red emission for MR-DVD (BL3 channel), and orange emission for PI (BL2 channel).2.2.5. Nuclear Condensation and Lysosomal Activity Assay 
After $24 \mathrm{~h}$ of treatment with the tested solutions, $300 \mu \mathrm{L}$ of blood cell culture was introduced in flow cytometry tubes, $2 \mu \mathrm{L}$ of Hoechst 33,342 stain was added, and blood cells were mixed well. After this process, $50 \mu \mathrm{L}$ of acridine orange (AO) $1.0 \mu \mathrm{M}$ was added, and the cells were incubated $30 \mathrm{~min}$ at room temperature into darkness. After incubation, $1 \mathrm{~mL} \mathrm{FCB}$ was added; the cells were examined at flow cytometer. UV excitation and blue emission for Hoechst 33,342 (VL2) at $488 \mathrm{~nm}$, and green emission acridine orange (BL1 channel) were used for examination.

\subsubsection{Total ROS Activity Assay}

After $24 \mathrm{~h}$ treatments with the tested solutions, $100 \mu \mathrm{L}$ of ROS Assay Stain solution was added for each $1 \mathrm{~mL}$ of blood cell culture in flow cytometry tubes and mixed well. Next, the cells were incubated for $60 \mathrm{~min}$ at $37^{\circ} \mathrm{C}$, in an incubator with $5 \% \mathrm{CO}_{2}$. After incubation, the blood cells were analyzed by flow cytometry, using a $488 \mathrm{~nm}$ excitation and green emission for ROS (BL1 channel).

\subsubsection{Cell Cycle Analysis}

Blood cells were treated with UA $(25-125 \mu \mathrm{g} / \mathrm{mL})$, UBA and UBE $(75-500 \mu \mathrm{g} / \mathrm{mL})$ and incubated for $24 \mathrm{~h} ; 1 \mathrm{~mL}$ of each cell culture was washed in FCB, introduced in flow cytometry tubes, and fixed with $50 \mu \mathrm{L}$ ethanol for $10 \mathrm{~min}$. After this process, the cells were treated with PI $(20 \mu \mathrm{g} / \mathrm{mL})$ and RNase A $(30 \mu \mathrm{g} / \mathrm{mL})$ and incubated for $30 \mathrm{~min}$ at room temperature, into darkness. After this time, $1 \mathrm{~mL} \mathrm{FCB}$ was added, and the cell cycle distribution was detected at flow cytometer, using a $488 \mathrm{~nm}$ excitation and orange emission for PI (BL2 channel).

\subsubsection{Cell Proliferation Assay}

After $24 \mathrm{~h}$ of treatment, $1 \mathrm{~mL}$ of blood cell culture was incubated with $50 \mu \mathrm{M}$ EdU $(500 \mu \mathrm{L})$, at $37^{\circ} \mathrm{C}$, for $2 \mathrm{~h}$. Then, the cells were fixed $(100 \mu \mathrm{L}$ of $4 \%$ paraformaldehyde in PBS) and permeabilized (100 $\mu \mathrm{L}$ of Triton X-100 $1 \times)$. After washing in 3\% BSA in flow cytometry $(2 \mathrm{~mL})$ and centrifuging at $300 \times g$ for $5 \mathrm{~min}$, at $4{ }^{\circ} \mathrm{C}$, the blood cells were incubated with a reaction mix (500 $\mu \mathrm{L}), 30 \mathrm{~min}$ at room temperature, into darkness. After washing in permeabilization buffer $(2 \mathrm{~mL})$ and centrifuging $\left(300 \times \mathrm{g}, 5 \mathrm{~min}\right.$, at $\left.4{ }^{\circ} \mathrm{C}\right), 1 \mathrm{~mL}$ FCB was added. Finally, the blood cells were examined by flow cytometry, using a $488 \mathrm{~nm}$ excitation and green emission for EdU-iFluor 488 (BL1).

\subsubsection{Statistical Analysis}

All analyses were performed in triplicate, and the obtained results were presented as means values \pm standard deviation (SD). Our results are presented as percent (\%) of cell and nuclear apoptosis, caspase 3/7 activity, autophagy, cell cycle, DNA synthesis, and count $\left(\times 10^{4}\right)$ of oxidative cellular stress after flow cytometry analyses were performed with SPSS v. 23 software, IBM, 2015. The Levene test was analyzed for homogeneity of variances of samples, while paired $t$-test, ANOVA [68], was used to establish the differences between samples and controls, and $p<0.05$ was considered statistically significant. Figures 2, 4, 6, 7, 9, 11 and 13 were made with Attune Cytometric Software v.1.2.5, Applied Biosystems, 2010 (Bedford, MA, USA). Figures 3, 5, 8, 10, 12 and 14 were made by the v. 14.8.1, 2014 of MedCalc program (Ostend, Belgium).

\section{Results}

\subsection{Usnea Barbata Dry Extracts and Usnic Acid Isolation}

The obtained chromatograms in both UHPLC determinations from Sections 2.1.1 and 2.1.2 are presented in Figure 1. From $12.8 \mathrm{mg}$ UBEA, $3.6 \mathrm{mg}$ of isolated usnic acid (Figure 1d) with $89.36 \%$ purity was obtained. The yield of this process was $28.15 \%$. 

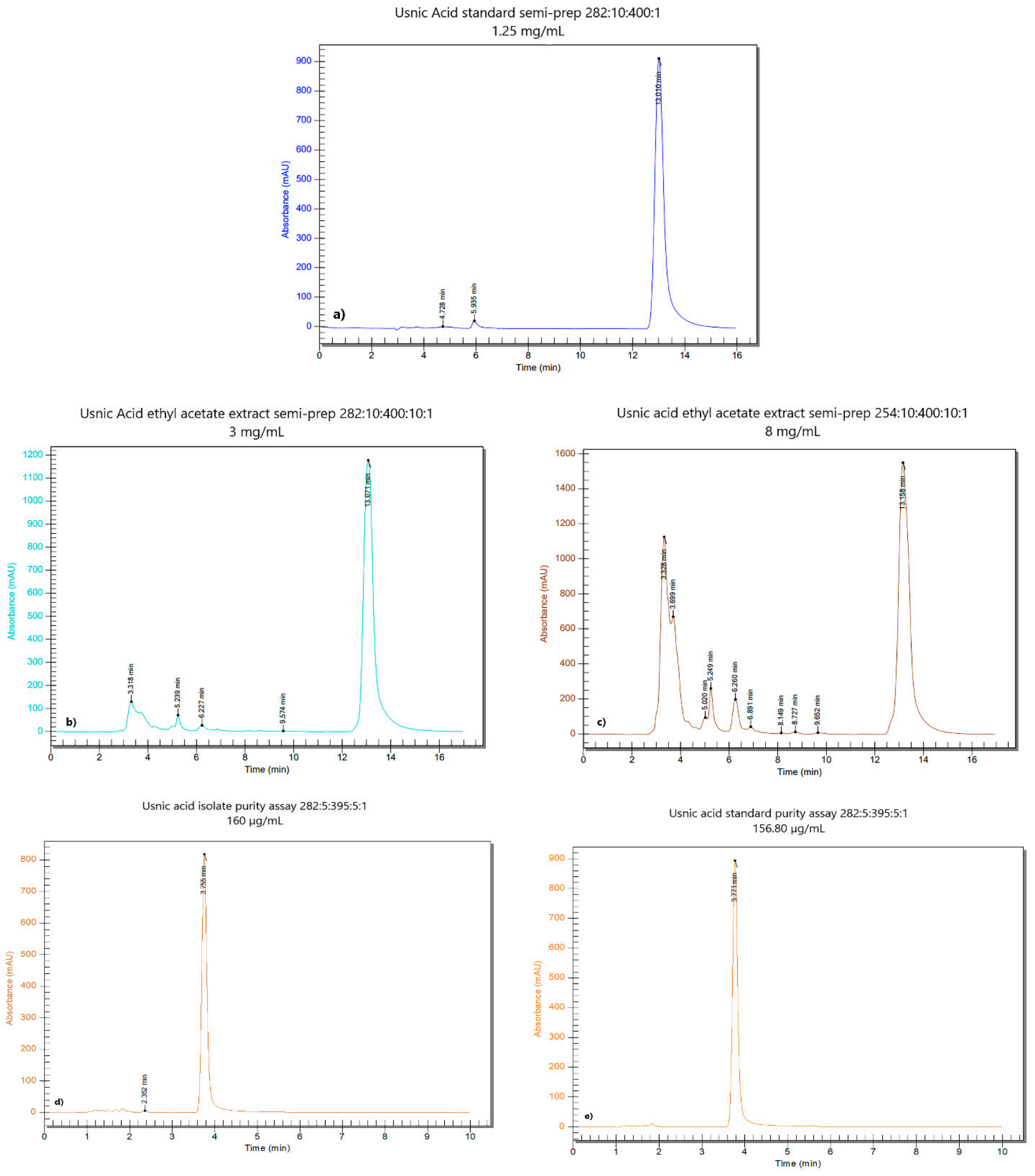

Figure 1. The chromatograms of usnic acid and sample solution for usnic acid separation; (a-c) chromatograms of usnic acid from semi-preparative chromatography, at the same flow rate $(10 \mathrm{~mL} / \mathrm{min})$ and different wavelengths and concentrations: (a) usnic acid standard at $282 \mathrm{~nm}$ and $1.25 \mathrm{mg} / \mathrm{mL}$; (b) usnic acid in UBEA at $282 \mathrm{~nm}$ and $3 \mathrm{mg} / \mathrm{mL}$; (c) usnic acid in UBEA at $254 \mathrm{~nm}$ and $8 \mathrm{mg} / \mathrm{mL}$; (d,e) chromatograms obtained at $282 \mathrm{~nm}$ from purity determination of isolated usnic acid: (d) sample solution (usnic acid isolate) (e) usnic acid standard solution. 


\subsection{In Vitro Analysis of the Biological Effects of UA, UBA, and UBE on Human Blood Cells \\ 3.2.1. Cell Apoptosis Assay}

Cell apoptosis induced by UA, UBA, and UBE treatments was determined based on morphology and cell membrane integrity in blood cell cultures. The obtained results are illustrated in Figure 2A-C and Figure 3a-c (V-cell viability, EA-early apoptosis, LA-late apoptosis, N-necrosis).

The influence of UA $(25,50,75,125 \mu \mathrm{g} / \mathrm{mL})$ on blood cells viability and apoptosis is presented in Figure 2A(b-e) and Figure 3a.

It can be noted that the viability of blood cells treated with $25 \mu \mathrm{g} / \mathrm{mL}$ of UA (Figure 2A(a,b)) insignificantly decreased in comparison with the solvent control: $96.45 \pm 0.27 \%$ vs. $96.89 \pm 0.14 \%$ $(p \geq 0.05$, Figure 3a). On the other hand, a concentration of $50 \mu \mathrm{g} / \mathrm{mL}$ of UA on blood cell cultures (Figure $2 \mathrm{~A}(\mathrm{a}, \mathrm{c})$ ) determined reduced cell viability reported to $1 \%$ DMSO: $95.75 \pm 0.63 \%$ vs. $96.89 \pm 0.14 \%(p<0.05$, Figure $3 a)$.

Likewise, these low concentrations of UA ( 25 and $50 \mu \mathrm{g} / \mathrm{mL})$ induce insignificant differences of early apoptosis (Figure $2 \mathrm{~A}(\mathrm{a}-\mathrm{c})$ ) collated to control: $3.12 \pm 0.26 \% ; 3.69 \pm 0.71 \%$ vs. $2.72 \pm 0.16 \%$ ( $p \geq 0.05$, Figure $3 a)$.

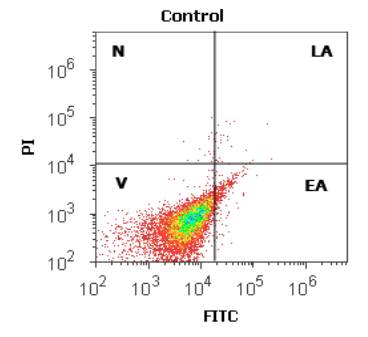

A.

(a)

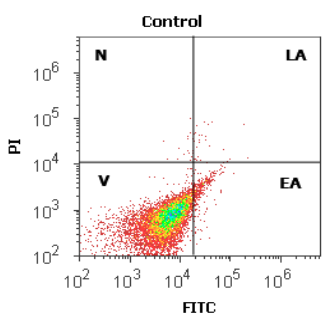

B.

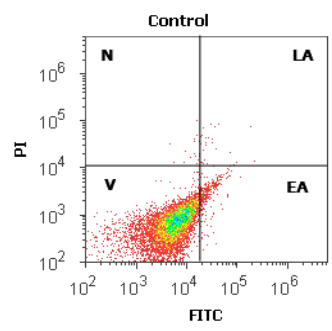

C.

(a)

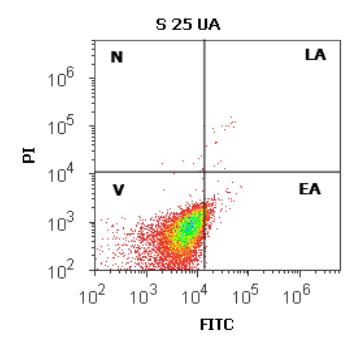

(b)

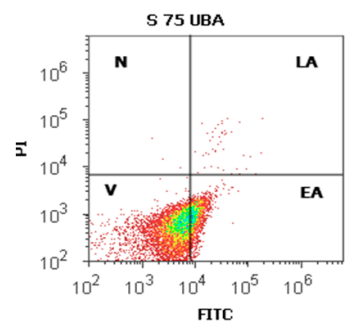

(b)

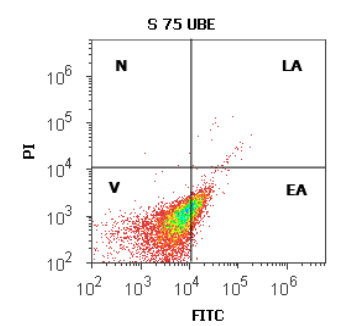

(b)

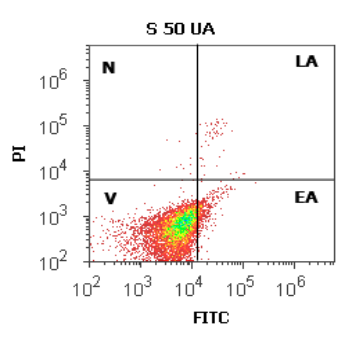

(c)

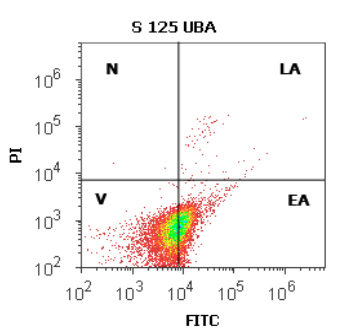

(c)

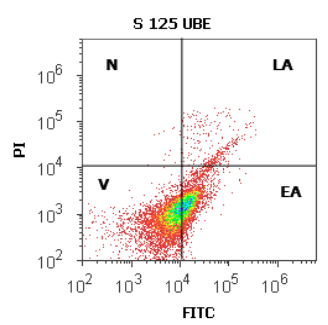

(c)

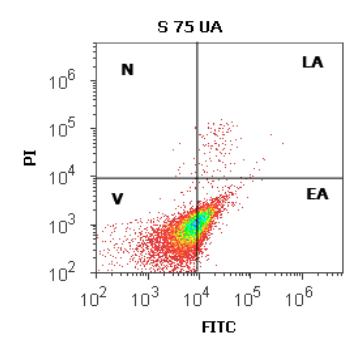

(d)

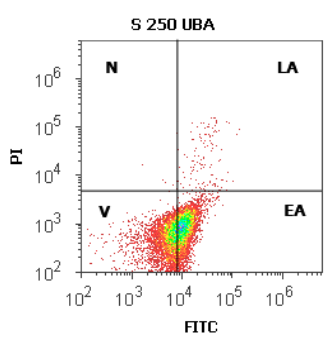

(d)

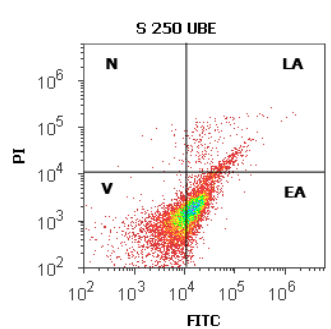

(d)

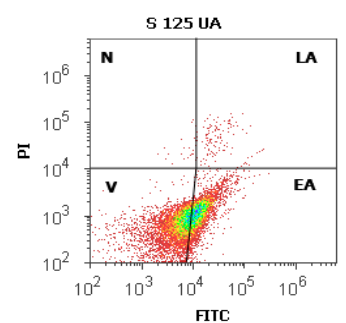

(e)

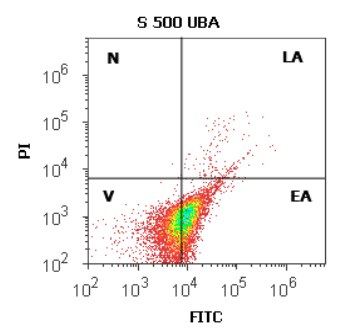

(e)

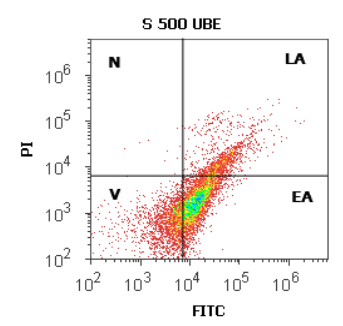

(e)

Figure 2. Cell apoptosis models of usnic acid (UA), $U$. barbata acetone (UBA), and $U$. barbata ethanol (UBE) treatments in normal blood cell cultures. Annexin V-FITC/PI patterns of $1 \%$ dimethyl sulfoxide (DMSO) Negative Control (A(a), B(a), $\mathbf{C}(\mathbf{a})) ; \mathbf{A}(\mathbf{b}-\mathbf{e})$ UA 25, 50, 75, $125 \mu \mathrm{g} / \mathrm{mL} ; \mathbf{B}(\mathbf{b}-\mathbf{e})$ UBA 75, 125, 250, $500 \mu \mathrm{g} / \mathrm{mL}$; and C(b-e) UBE 75, 125, 250, 500 $\mu \mathrm{g} / \mathrm{mL}$. 


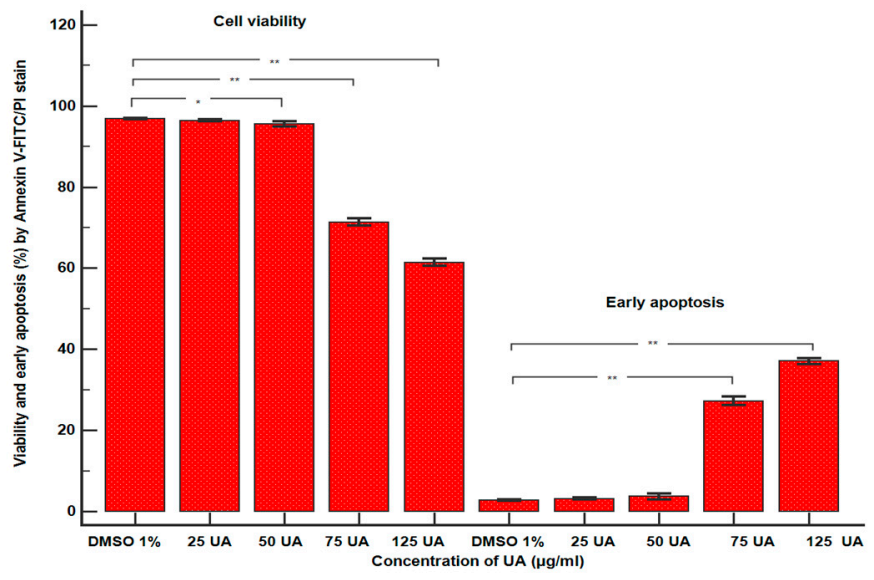

(a)

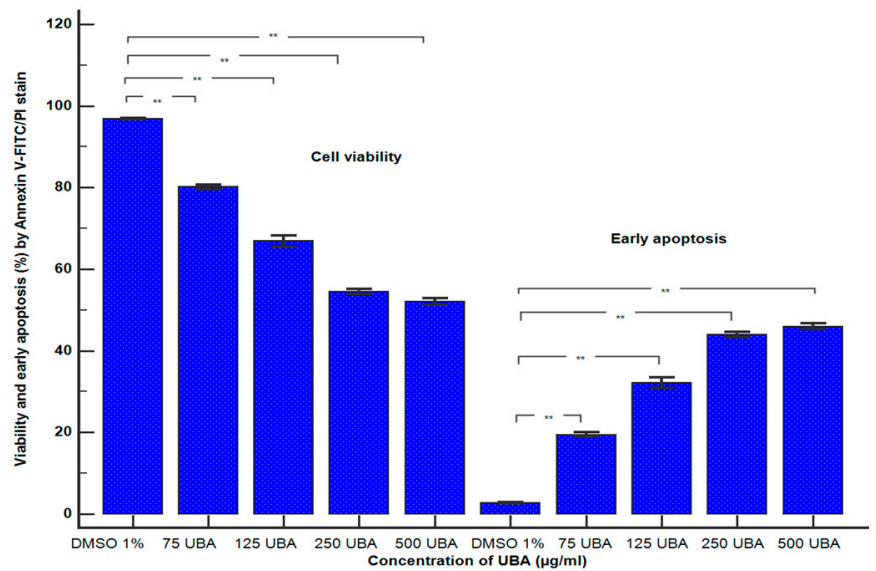

(b)

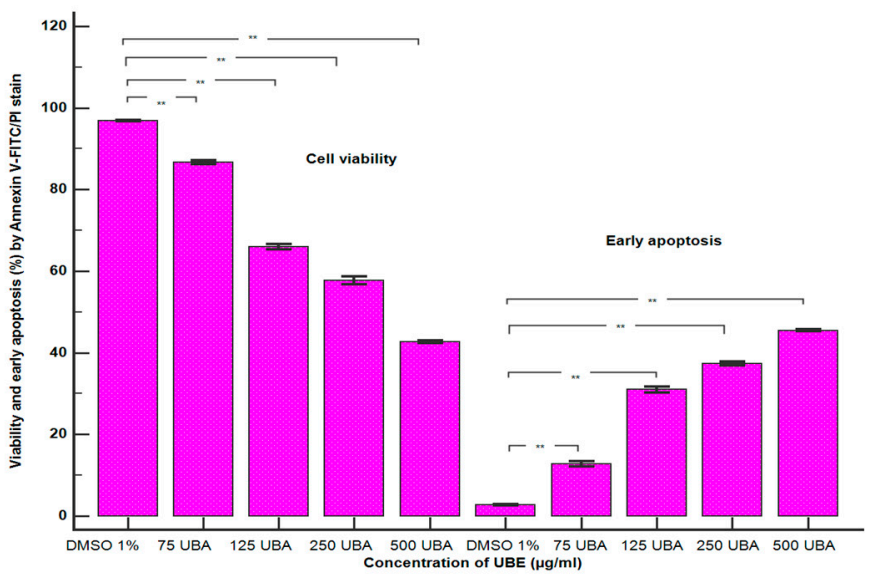

(c)

Figure 3. Statistical analysis of cell apoptosis: (a) UA; (b) UBA; (c) UBE. * $p<0.05$ and ${ }^{* *} p \leq 0.001$ represent significant statistical differences between control and samples made by paired samples $t$-test.

Moreover, higher concentrations of UA (75 and $125 \mu \mathrm{g} / \mathrm{mL}$ ) significantly influenced both parameters (Figure $2 \mathrm{~A}(\mathrm{a}, \mathrm{d}, \mathrm{e})$ ). They induced an evident decline of cell viability $(71.34 \pm 0.90 \% ; 61.43 \pm 0.88 \%$ vs. $96.89 \pm 0.14 \%, p<0.001)$, and an augmentation of early apoptosis ( $27.27 \pm 1.00 \% ; 37.04 \pm 0.66 \%$ vs. $2.72 \pm 0.16 \%, p<0.001$, Figure $3 a)$.

UBA activity $(75,125,250,500 \mu \mathrm{g} / \mathrm{mL})$ on blood cells viability and apoptosis compared with $1 \%$ DMSO is shown in Figure $2 \mathrm{~B}(\mathrm{a}-\mathrm{e})$ and Figure $3 \mathrm{~b}$.

The obtained data revealed that $75 \mu \mathrm{g} / \mathrm{mL}$ of UBA (Figure $2 \mathrm{~B}(\mathrm{a}, \mathrm{b})$ ) determined a diminution in cell viability: $80.16 \pm 0.57 \%$ vs. $96.89 \pm 0.14 \%,(p<0.001)$; also, it induced an increase of cell apoptosis: $19.45 \pm 0.60 \%$ vs. $2.72 \pm 0.16 \%$ ( $p<0.001$, Figure $3 b)$.

Higher concentrations of UBA $(125,250$, and $500 \mu \mathrm{g} / \mathrm{mL})$ remarkably reduced blood cells viability, triggering apoptosis (Figure $2 \mathrm{~B}(\mathrm{c}-\mathrm{e})$ ). Hence, previously mentioned concentrations of UBA had a significant cytotoxic effect on blood cells, with diminishing viability compared with solvent control: $66.93 \pm 1.37 \%$; $54.57 \pm 0.65 \% ; 52.15 \pm 0.81 \%$; vs. $96.89 \pm 0.14 \%(p<0.001$, Figure $3 b)$. Moreover, these results indicated high rise of early apoptosis: $32.18 \pm 1.22 \% ; 43.99 \pm 0.66 \% ; 45.98 \pm 0.78 \%$ vs. $2.72 \pm 0.16 \%(p<0.001$, Figure $3 b)$.

The flow cytometry results regarding UBE effects on the apoptosis process are indicated in Figure $2 \mathrm{C}(\mathrm{b}-\mathrm{e})$ and Figure $3 \mathrm{c}$. 
It can be seen that $75 \mu \mathrm{g} / \mathrm{mL}$ of UBE (Figure $2 \mathrm{C}(\mathrm{a}, \mathrm{b})$ ) determined a diminution of blood cell viability reported to $1 \%$ DMSO: $86.66 \pm 0.45 \%$ vs. $96.89 \pm 0.14 \%, p<0.001$; therefore, it raised their apoptosis: $12.81 \pm 0.66 \%$ vs. $2.72 \pm 0.16 \%(p<0.001$, Figure $3 c)$.

In addition, higher concentrations of $\operatorname{UBE}(125,250$, and $500 \mu \mathrm{g} / \mathrm{mL})$ had a considerable cytotoxic effect on blood cells (Figure $2 \mathrm{C}(\mathrm{a}, \mathrm{c}-\mathrm{e})$ ); viability has substantial reduced values, compared with the solvent control: $65.96 \pm 0.68 \% ; 57.91 \pm 0.96 \% ; 42.65 \pm 0.32 \%$ vs. $96.89 \pm 0.14 \%(p<0.001$, Figure $3 c)$. In addition, our results indicate that UBE at the same concentrations promoted significantly augmented levels of early apoptosis reported to $1 \%$ DMSO: $30.19 \pm 0.77 \% ; 30.99 \pm 0.77 \% ; 45.52 \pm 0.18 \%$ vs. $2.72 \pm 0.16 \%$ ( $p<0.001$, Figure $3 c)$.

Finally, Figure 2 indicates that insignificant late apoptosis and necrosis phenomena occurred in blood cell cultures after $24 \mathrm{~h}$ treatment.

\subsubsection{Caspase $3 / 7$ Activity Assay}

The apoptotic effects of UA, UBA, and UBE evaluated by measuring the caspase-3/7 activity compared with $1 \%$ DMSO, were registered in Figure $4 \mathrm{~A}-\mathrm{C}$ and Figure $5 \mathrm{a}-\mathrm{c}$.

We noted that the minimum concentration of UA $(25 \mu \mathrm{g} / \mathrm{mL})$ induces a low increase of cell apoptosis (Figure $4 \mathrm{~A}(\mathrm{a}, \mathrm{b})$ ) reported to control $(3.75 \pm 0.36 \%$ vs. $1.38 \pm 0.03 \%, p<0.01$, Figure 5a). Forwards, a remarkable increase of caspase- $3 / 7$ activation was registered on blood cell cultures treated with 50,75 , and $125 \mu \mathrm{g} / \mathrm{mL}$ of UA (Figure $4 \mathrm{~A}(\mathrm{a}, \mathrm{c}-\mathrm{e})$ ) in comparison with $1 \%$ DMSO: $6.81 \pm 0.43 \% ; 29.49 \pm 1.96 \% ; 44.74 \pm 0.41 \%$ vs. $1.38 \pm 0.03 \%$ $(p<0.001$, Figure 5a).

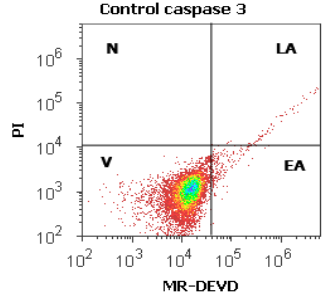

A.

(a)

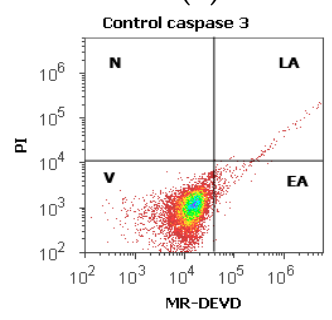

B.

(a)

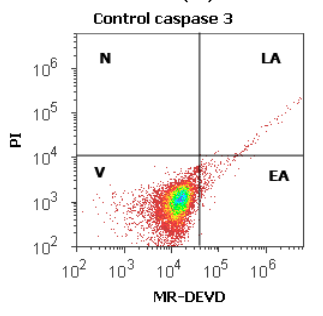

c.

(a)

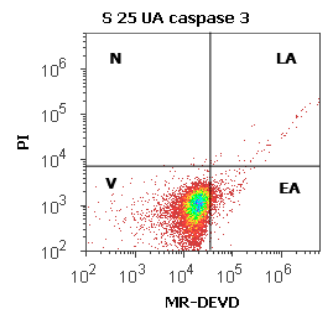

(b)

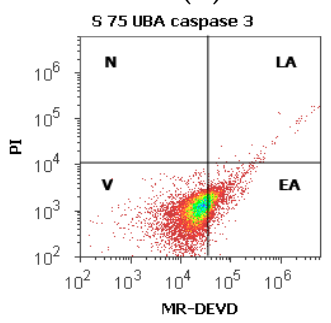

(b)

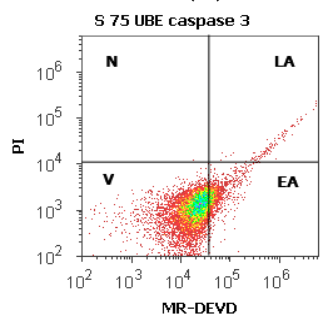

(b)

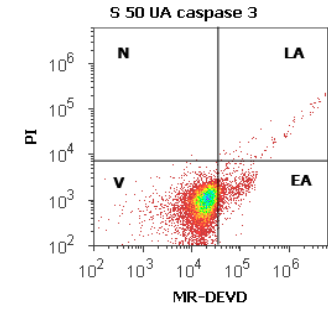

(c)

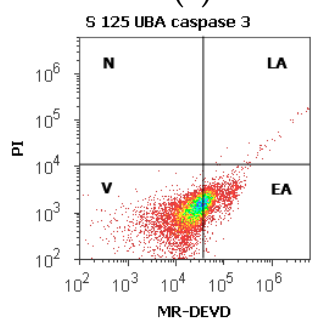

(c)

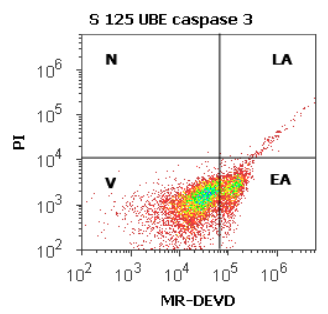

(c)

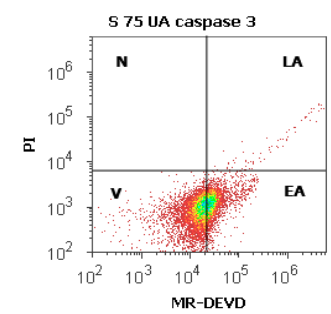

(d)

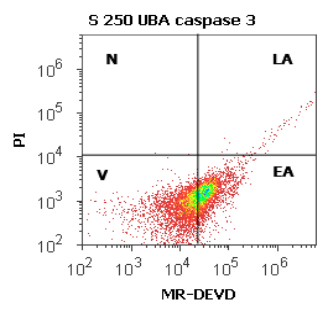

(d)

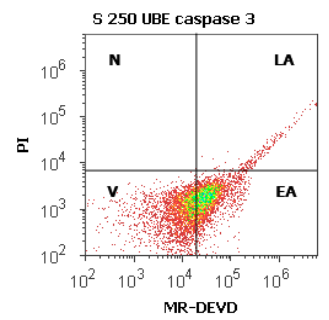

(d)

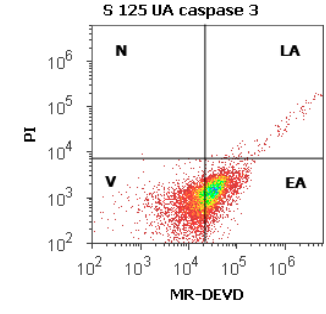

(e)

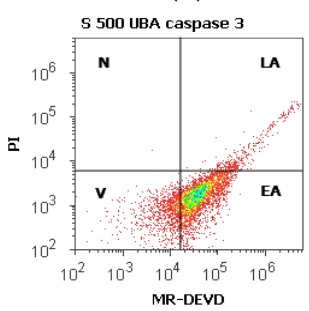

(e)

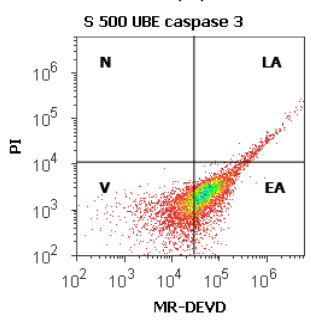

(e)

Figure 4. Caspase $3 / 7$ activity status of UA, UBA, and UBE treatments in normal blood cell cultures. MR-DEVD/PI patterns of $1 \%$ DMSO as Negative Control (A(a), B(a), C(a)); A(b-e) UA 25, 50, 75, $125 \mu \mathrm{g} / \mathrm{mL}$; B(b-e) UBA 75, 125, 250, 500 $\mu \mathrm{g} / \mathrm{mL}$; C(b-e) UBE 75, 125, 250, $500 \mu \mathrm{g} / \mathrm{mL}$. 


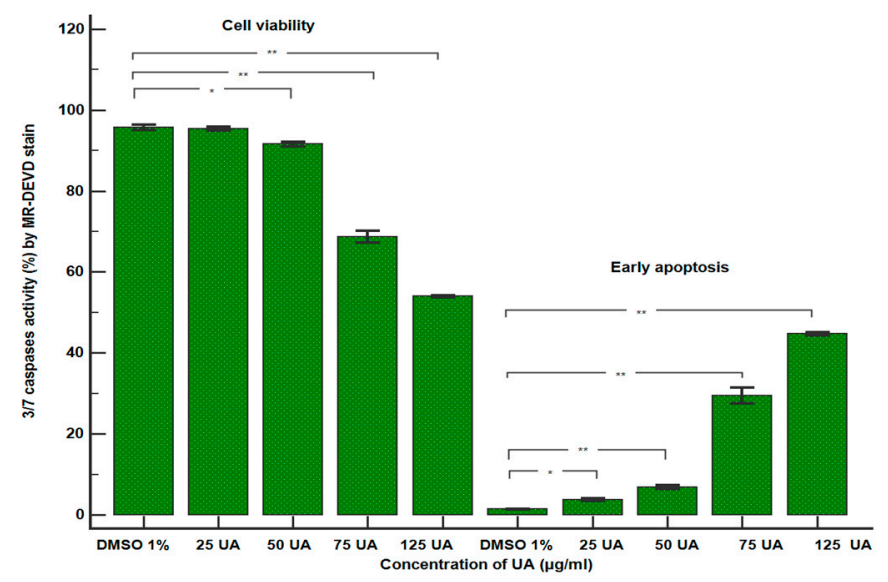

(a)

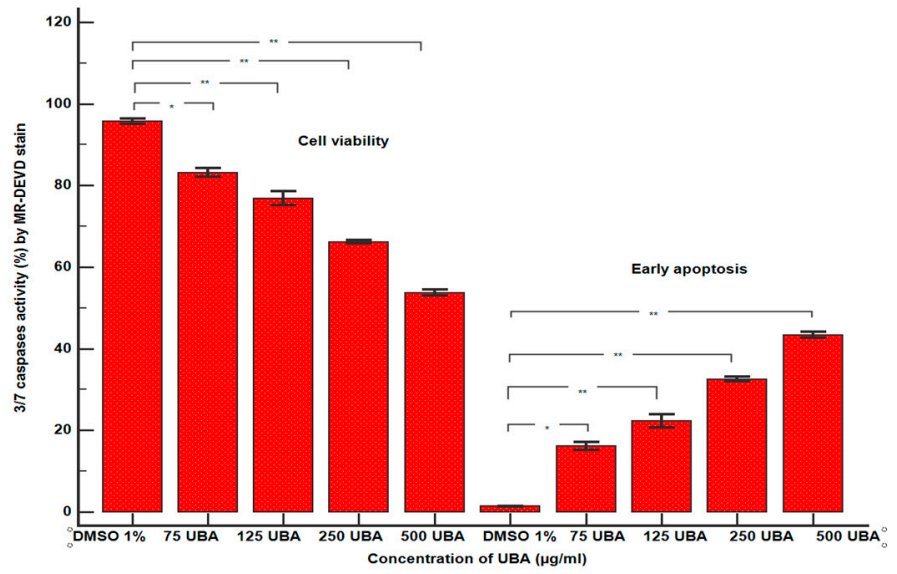

(b)

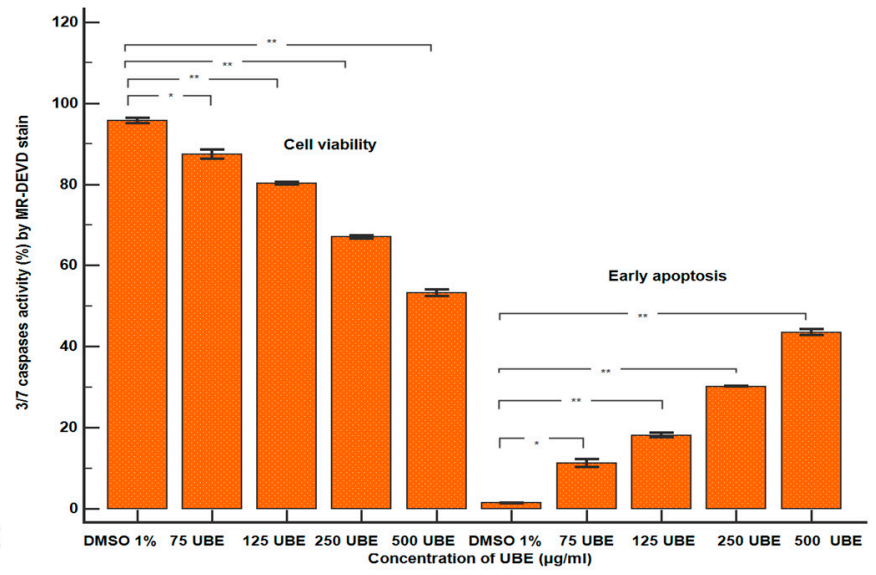

(c)

Figure 5. Statistical analysis of caspase $3 / 7$ activity: (a) UA; (b) UBA; (c) UBE. ${ }^{*} p<0.01$ and ${ }^{* *} p<0.001$ represent significant statistical differences between the control and samples made by paired samples $t$-test.

Remarkably, the lowest UBA concentration $(75 \mu \mathrm{g} / \mathrm{mL}$, Figure $4 \mathrm{~B}(\mathrm{a}, \mathrm{b}))$ induces mild apoptosis in blood cells cultures: $16.16 \pm 0.93 \%$ vs. $1.38 \pm 0.03 \%(p<0.01$, Figure $5 b)$. Furthermore, we aimed to confirm that 125,250 , and $500 \mu \mathrm{g} / \mathrm{mL}$ of UBA produce significant blood cells apoptosis (Figure $4 \mathrm{~B}(\mathrm{c}-\mathrm{e})$ ). Consequently, we evaluated the intracellular activity of effector caspase $3 / 7$, and we observed that the biochemical cascade of reactions implied into pro-apoptotic signal has considerably increased more than 1\% DMSO: $22.35 \pm 1.58 \%$; $32.53 \pm 0.57 \% ; 43.57 \pm 0.73 \%$ vs. $1.38 \pm 0.03 \%$, $(p<0.001$, Figure $5 b)$.

Similarly, $75 \mu \mathrm{g} / \mathrm{mL}$ of UBE (Figure $4 \mathrm{C}(\mathrm{a}, \mathrm{b})$ ) induced a low apoptosis in blood cells cultures: $11.25 \pm 0.96 \%$ vs. $1.38 \pm 0.03 \%$ ( $p<0.01$, Figure 5 c). Higher UBE concentrations $(125,250$, and $500 \mu \mathrm{g} / \mathrm{mL})$ triggered proapoptotic signal with considerable increased values (Figure $4 \mathrm{C}(\mathrm{a}, \mathrm{c}-\mathrm{e})$ ) compared with solvent control: $18.15 \pm 0.52 \% ; 30.18 \pm 0.09 \%$; $43.54 \pm 0.72 \%$ vs. $1.38 \pm 0.03 \%$ ( $p<0.001$, Figure $5 c)$.

Our results indicate a similar trend to the previous assay in UA, UBA, and UBE activity on blood cell cultures (Figure 2). The effect on caspase 3/7 activity is directly proportional with the sample concentration, which registers significantly increased levels at high doses, and decreases in the order of: usnic acid, $U$. barbata dry extract in acetone, and ethanol (Figures 4 and 5). 


\subsubsection{Nuclear Condensation and Lysosomal Activity Assay}

Apoptosis is the mode of cell death that includes pyknosis; in this assay, pyknotic nuclei were stained with Hoechst 33,342 on blood cell cultures. Another aimed objective was an evaluation of lysosomal activity directly related to autophagy.

Therefore, blood cells were also colored with acridine orange (AO). The obtained results were synthesized in Figures 6 and 7.

The lowest concentration of UA $(25 \mu \mathrm{g} / \mathrm{mL}$, Figure $6 \mathrm{~A}(\mathrm{a}, \mathrm{b}))$ induced an insignificant increase of nuclear condensation: $1.36 \pm 0.20 \%$ vs. $1.03 \pm 0.03 \%(p \geq 0.05$, Figure $8 \mathrm{a})$ and a mild increase of lysosomal activity (Figure 7A(a,b)) reported to solvent control: $6.59 \pm 0.33 \%$ vs. $1.04 \pm 0.04 \%$ ( $p \leq 0.01$, Figure $8 a)$.

The higher concentrations of UA (50, 75, and $125 \mu \mathrm{g} / \mathrm{mL}$, Figure $6 \mathrm{~A}(\mathrm{a}, \mathrm{c}-\mathrm{e}))$ continued to have directly proportional effects on nuclear shrinkage: $1.49 \pm 0.02 \% ; 3.00 \pm 0.10 \%$; $3.19 \pm 0.30 \%$ vs. $1.03 \pm 0.03 \%$ ( $p \leq 0.01 ; p<0.001$, Figure $8 \mathrm{a}$ ). In addition, the same UA concentrations (Figure $7 \mathrm{~A}(\mathrm{a}, \mathrm{c}-\mathrm{e})$ ) induced a substantial increase of the autophagy levels compared with $1 \%$ DMSO: $12.97 \pm 1.55 \% ; 21.72 \pm 0.38 \% ; 27.05 \pm 1.52 \%$ vs. $1.04 \pm 0.04 \%$ $(p \leq 0.01 ; p<0.001$, Figure 8a).

Nuclear shrinkage and autophagy were concomitantly examined to evaluate the mechanism of UBA cytotoxicity on blood cells cultures. Thereby, it can be noted that $75 \mu \mathrm{g} / \mathrm{mL}$ of UBA had minimal effects on both processes (Figure $6 \mathrm{~B}(\mathrm{a}, \mathrm{b})$ and Figure $7 \mathrm{~B}(\mathrm{a}, \mathrm{b})$ ) compared with $1 \%$ DMSO: nuclear condensation $1.41 \pm 0.09 \%$ vs. $1.03 \pm 0.03 \%,(p<0.05$, Figure $8 b$ ), and autophagy $4.64 \pm 0.38 \%$ vs. $1.04 \pm 0.04 \%$ ( $p \leq 0.01$, Figure $8 b)$.

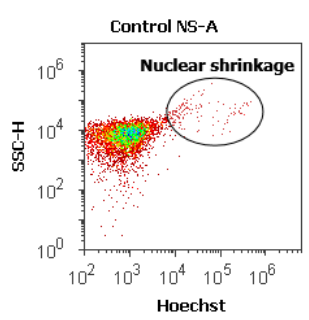

A.

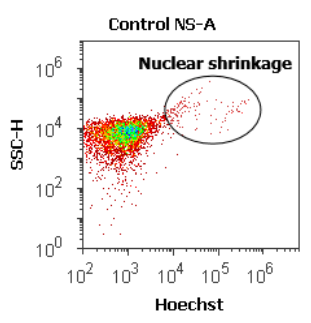

B.

(a)

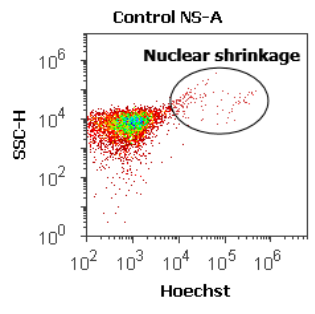

C.

(a)

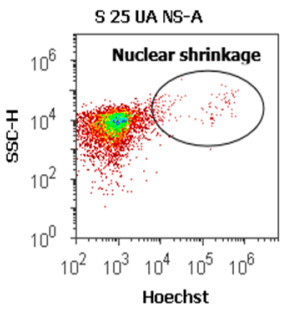

(b)

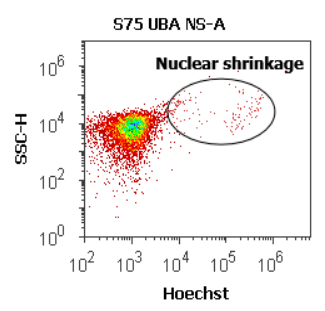

(b)

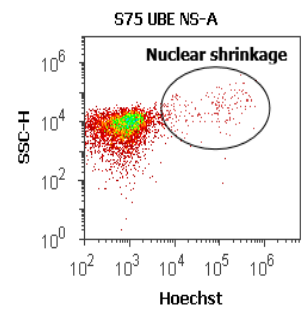

(b)

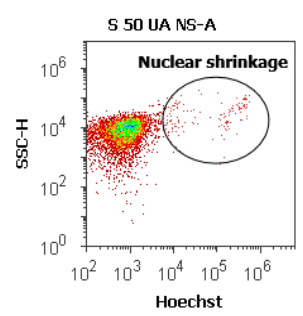

(c)

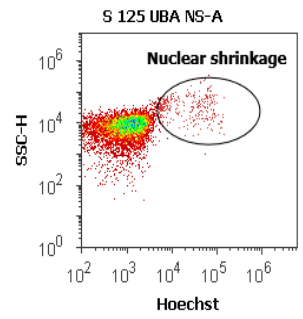

(c)

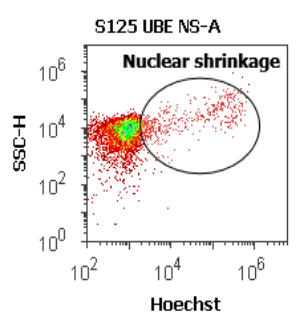

(c)

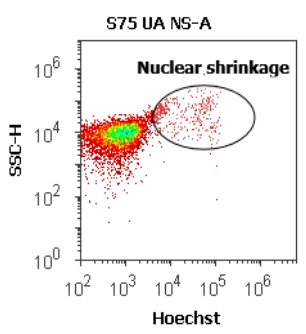

(d)

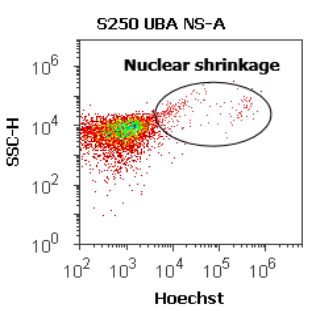

(d)

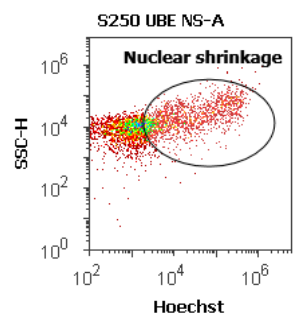

(d)

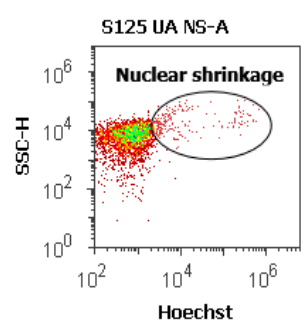

(e)

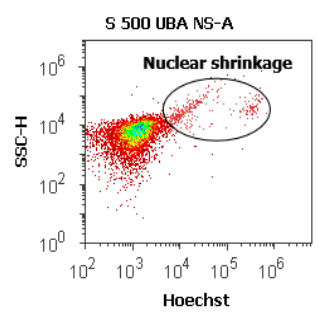

(e)

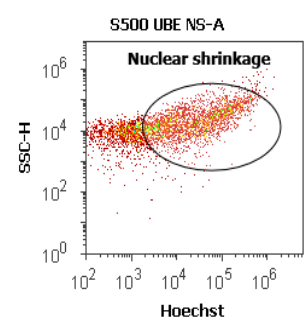

(e)

Figure 6. Nuclear shrinkage status of UA, UBA, and UBE treatments in normal blood cell cultures. Hoechst patterns of UA 25, 50, 75, $125 \mu \mathrm{g} / \mathrm{mL} \mathbf{A}(\mathbf{b}-\mathbf{e}) ; \mathbf{B}(\mathbf{b}-\mathbf{e})$ UBA 75, 125, 250, $500 \mu \mathrm{g} / \mathrm{mL} ; \mathbf{C}(\mathbf{b}-\mathbf{e}) \mathrm{UBE} 75,125,250,500 \mu \mathrm{g} / \mathrm{mL}$ reported to $1 \%$ $\operatorname{DMSO}(\mathbf{A}(\mathbf{a}), \mathbf{B}(\mathbf{a}), \mathbf{C}(\mathbf{a}))$. 


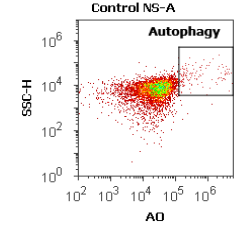

(a)

A.

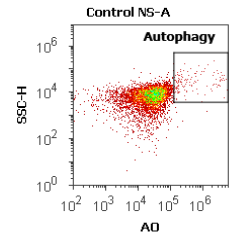

B.

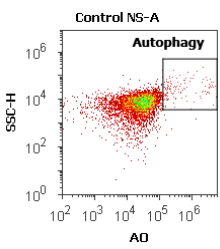

C.

(a)

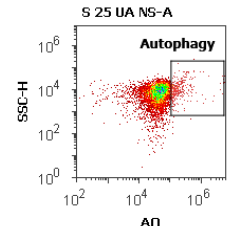

(b)

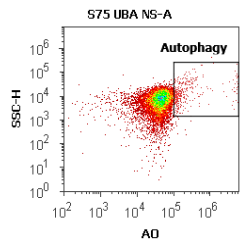

(b)

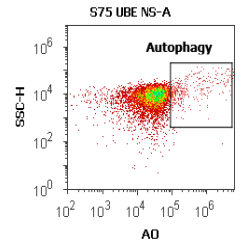

(b)

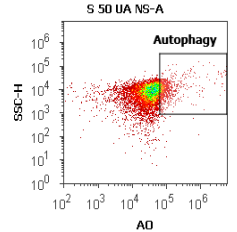

(c)

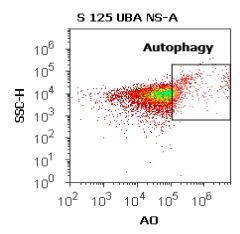

(c)

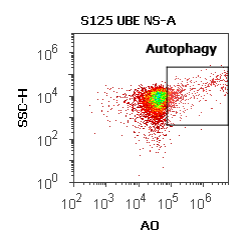

(c)

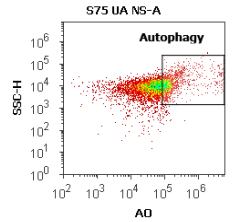

(d)

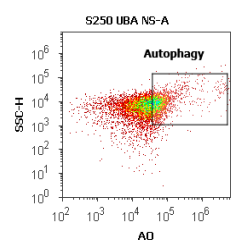

(d)

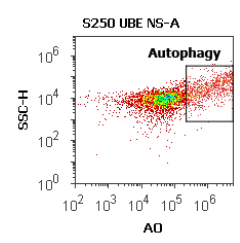

(d)

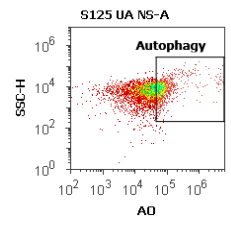

(e)

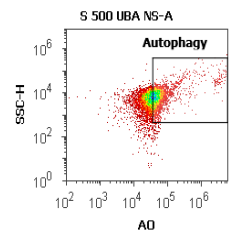

(e)

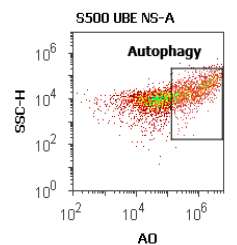

(e)

Figure 7. Autophagy status of UBA, UBA, and UBE treatments in normal blood cell cultures. Acridine orange patterns of UA 25, 50, 75, $125 \mu \mathrm{g} / \mathrm{mL} \mathrm{A(b-e);} \mathrm{B(b-e)} \mathrm{UBA} \mathrm{75,} \mathrm{125,} \mathrm{250,} 500 \mu \mathrm{g} / \mathrm{mL} ; \mathbf{C}(\mathbf{b}-\mathbf{e}) \mathrm{UBE} 75,125,250,500 \mu \mathrm{g} / \mathrm{mL}$ reported to $1 \%$ $\operatorname{DMSO}(\mathbf{A}(\mathbf{a}), \mathbf{B}(\mathbf{a}), \mathbf{C}(\mathbf{a}))$.

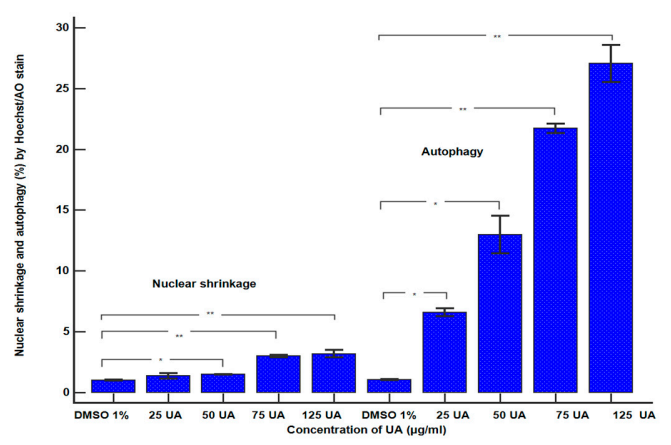

(a)

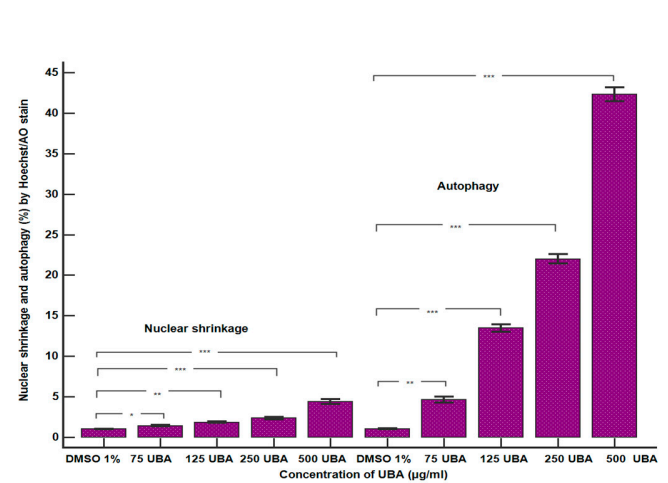

(b)

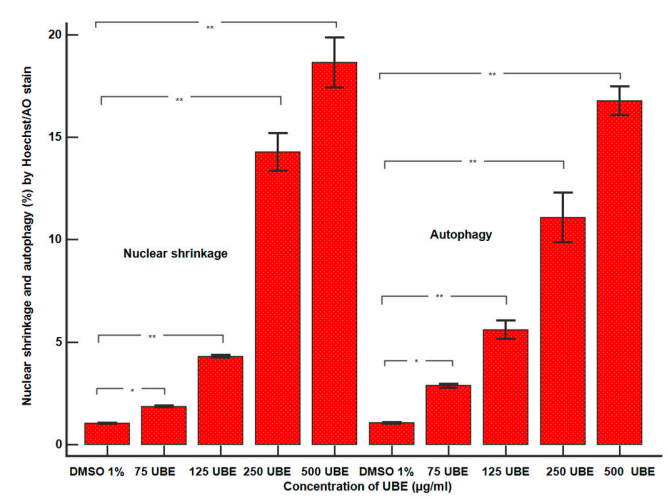

(c)

Figure 8. Statistical analysis of nuclear shrinkage and autophagy: (a) UA; (b) UBA; (c) UBE. ${ }^{*} p<0.05 .{ }^{* *} p \leq 0.01$, and ${ }^{* * *} p<0.001$ represent significant statistical differences between the control and samples made by paired samples $t$-test. 
On nuclear condensation, the following concentrations of UBA: 125,250 , and $500 \mu \mathrm{g} / \mathrm{mL}$ (Figure $6 \mathrm{~B}(\mathrm{a}, \mathrm{c}-\mathrm{e})$ ) continued to show mild effects reported to control: $1.85 \pm 0.10 \%$; $2.36 \pm 0.16 \% ; 4.41 \pm 0.32 \%$ vs. $1.03 \pm 0.03 \%(p<0.01, p \leq 0.001$, Figure $8 b)$. In addition, previously mentioned concentrations of UBA (Figure $7 \mathrm{~B}(\mathrm{a}, \mathrm{c}-\mathrm{e})$ ) significantly increased autophagy: $13.49 \pm 0.45 \% ; 21.99 \pm 0.57 \% ; 42.32 \pm 0.85 \%$ vs. $1.04 \pm 0.04 \%(p \leq 0.001$, Figure 8b).

Finally, $75 \mu \mathrm{g} / \mathrm{mL}$ UBE (Figure 6C(a,b)) showed a similar effect on nuclear contraction with UBA (Figure 7B(a,b)) at the same concentration as the solvent control: $1.85 \pm 0.03 \%$ vs. $1.03 \pm 0.03 \%$ ( $p \leq 0.01$, Figure $8 \mathrm{c}$ ).

However, this effect considerably increases at the following UBE higher concentrations $(125,250$ and $500 \mu \mathrm{g} / \mathrm{mL}$, Figure $6 \mathrm{C}(\mathrm{a}, \mathrm{c}-\mathrm{e}))$ reported to control: $4.29 \pm 0.06 \% ; 14.27 \pm 0.93 \%$; $18.64 \pm 1.22 \%$ vs. $1.03 \pm 0.03 \%(p \leq 0.001$, Figure $8 \mathrm{c})$

Besides, UBE acted slowly, inducing a moderate increase of the lysosomal activity (Figure $7 \mathrm{C}(\mathrm{a}-\mathrm{e})$ ) from $75 \mu \mathrm{g} / \mathrm{mL}$ to $500 \mu \mathrm{g} / \mathrm{mL}$ reported to $1 \%$ DMSO: $2.87 \pm 0.09 \%$; $5.59 \pm 0.44 \% ; 11.08 \pm 1.21 \% ; 16.77 \pm 0.69 \%$ vs. $1.04 \pm 0.04 \%(p \leq 0.01, p \leq 0.001$, Figure $8 \mathrm{c})$.

\subsubsection{Total ROS Activity Assay}

The ranges $25-125 \mu \mathrm{g} / \mathrm{mL}$ UA and $75-500 \mu \mathrm{g} / \mathrm{mL}$ UBA and UBE were selected to evaluate oxidative stress in blood cells by ROS level determination.

As shown in Figure 9A-C(a-e), except for 1\% DMSO, all samples (UA, UBA, and UBE) induced ROS generation, highlighted by the moving of the peaks to the right of the graph. Hence, the lowest concentration of UA $(25 \mu \mathrm{g} / \mathrm{mL})$ slowly stimulated ROS production (Figure $9 \mathrm{~A}(\mathrm{a}, \mathrm{b})$ ) reported to $1 \%$ DMSO: $34.33 \times 10^{4} \pm 4.04$ vs. $10.40 \times 10^{4} \pm 1.00(p<0.01$, Figure 10a). A remarkable increase in ROS levels was observed in blood cells treated with 50,75 , and $125 \mu \mathrm{g} / \mathrm{mL}$ of UA (Figure $9 \mathrm{~A}(\mathrm{a}, \mathrm{c}-\mathrm{e})$ ) compared with the negative control: $56.33 \times 10^{4} \pm 1.52 ; 80.33 \times 10^{4} \pm 0.57 ; 84.67 \times 10^{4} \pm 0.57$ vs. $10.40 \times 10^{4} \pm 1.00(p<0.001$, Figure 10a).

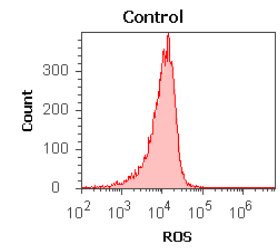

A.

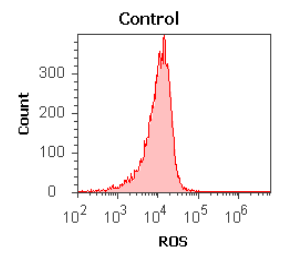

B.

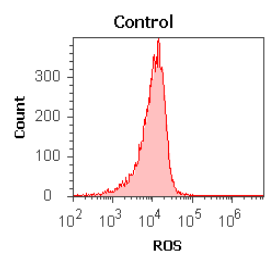

C.

(a)

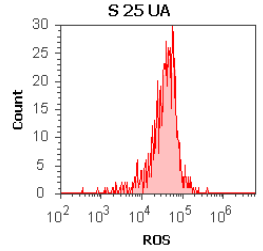

(b)

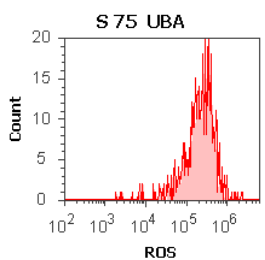

(b)

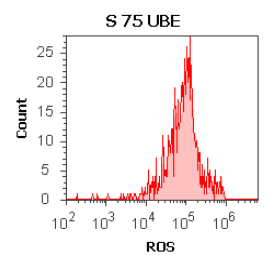

(b)

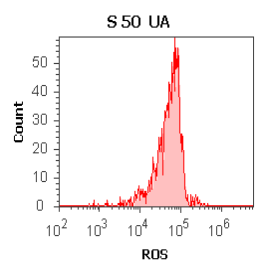

(c)

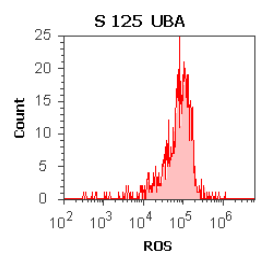

(c)

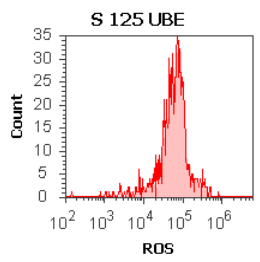

(c)

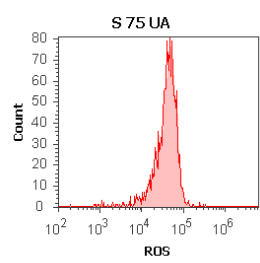

(d)

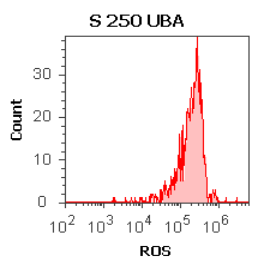

(d)

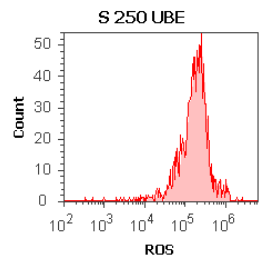

(d)

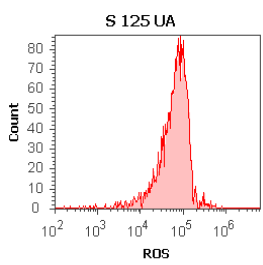

(e)

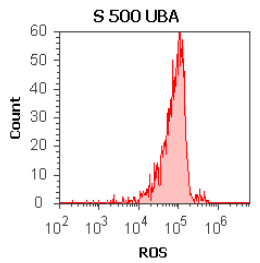

(e)

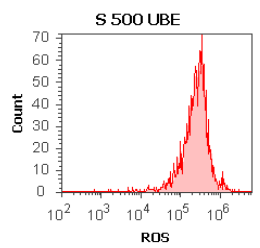

(e)

Figure 9. Reactive oxygen species (ROS) status of UA, UBA, and UBE treatments in normal blood cell cultures. ROS patterns of UA 25, 50, 75, $125 \mu \mathrm{g} / \mathrm{mL} \mathrm{A(b-e);} \mathrm{B(b-e)} \mathrm{UBA} \mathrm{75,} \mathrm{125,} \mathrm{250,} 500 \mu \mathrm{g} / \mathrm{mL}$; C(b-e) UBE 75, 125, 250, $500 \mu \mathrm{g} / \mathrm{mL}$ reported to $1 \% \operatorname{DMSO}(\mathbf{A}(\mathbf{a}), \mathbf{B}(\mathbf{a}), \mathbf{C}(\mathbf{a}))$. 


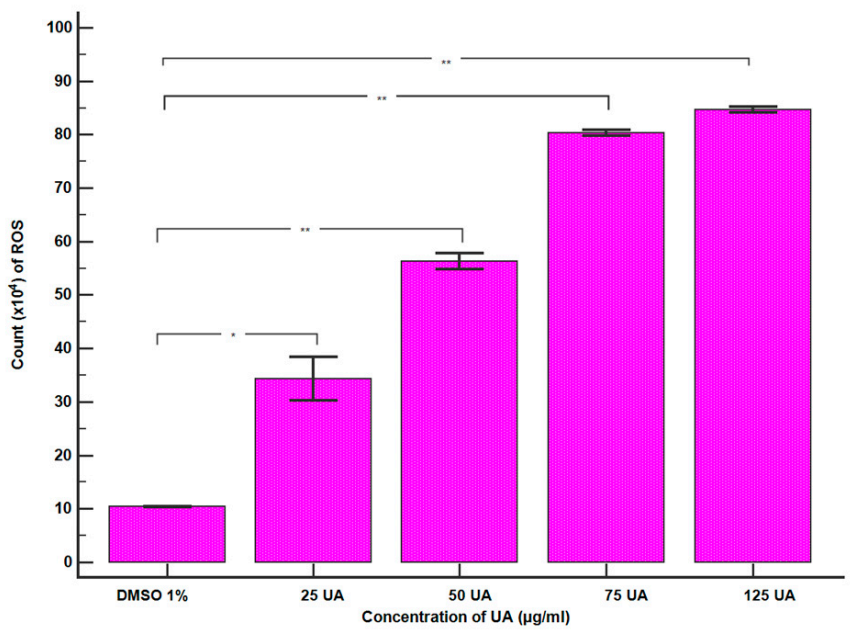

(a)

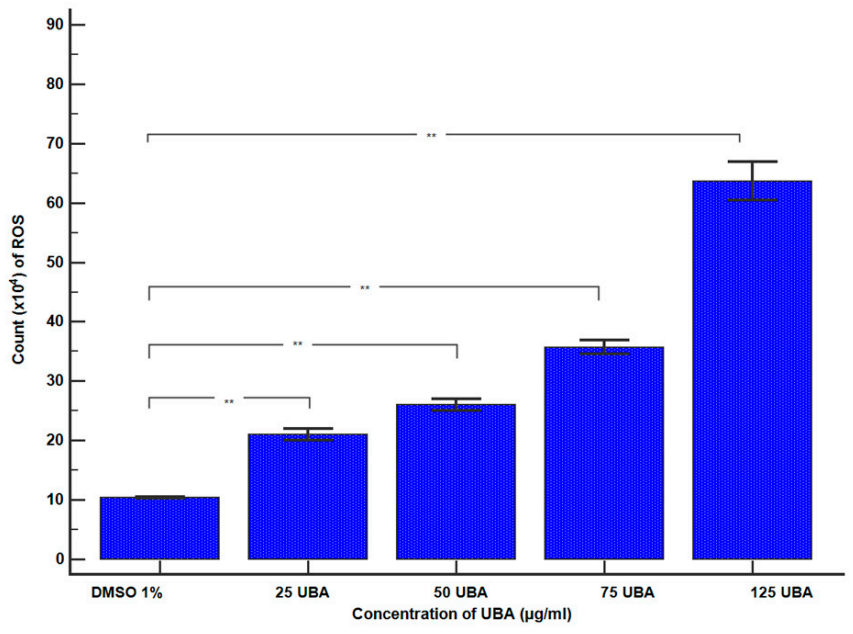

(b)

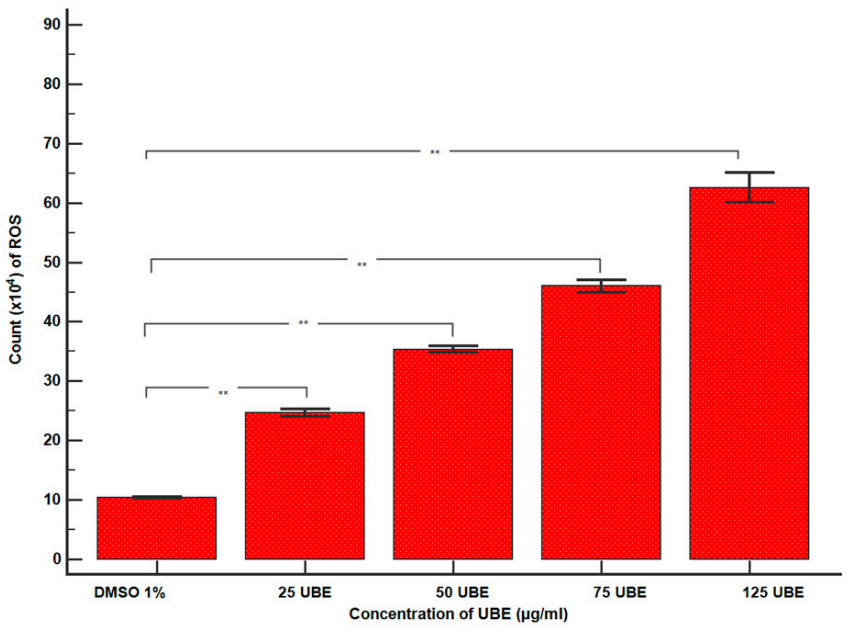

(c)

Figure 10. Statistical analysis of cellular oxidative stress: (a) UA; (b) UBA; (c) UBE. ${ }^{*} p<0.01$ and ${ }^{* *} p<0.001$ represent significant statistical differences between the control and samples made by paired samples $t$-test.

The lowest concentration of UBA $(75 \mu \mathrm{g} / \mathrm{mL})$ slightly stimulated ROS production (Figure $9 \mathrm{~B}(\mathrm{a}, \mathrm{b})$ ) compared with $1 \%$ DMSO: $21.00 \times 10^{4} \pm 1.00$ vs. $10.40 \times 10^{4} \pm 1.00$ $(p<0.001$, Figure 10b).

Subsequent higher concentrations of UBA $(125,250$, and $500 \mu \mathrm{g} / \mathrm{mL})$ continued to increase ROS levels (Figure $9 \mathrm{~B}(\mathrm{a}, \mathrm{c}-\mathrm{e})$ ) and the differences reported to solvent control remained significant: $26.00 \times 10^{4} \pm 1.00 ; 35.66 \times 10^{4} \pm 1.15 ; 63.66 \times 10^{4} \pm 3.21$ vs. $10.40 \times 10^{4} \pm 1.00$ $(p<0.001$, Figure 10b).

Likewise, $75,125,250$, and $500 \mu \mathrm{g} / \mathrm{mL}$ UBE considerably stimulated ROS production in blood cells, directly proportional with the concentrations (Figure 9C(a-d)).

Our results showed that ROS levels in blood cells compared with the negative control were as follows: $24.66 \times 10^{4} \pm 0.57 ; 35.63 \times 10^{4} \pm 0.57 ; 46.00 \times 10^{4} \pm 1.00$; $62.53 \times 10^{4} \pm 2.50$ vs. $10.40 \times 10^{4} \pm 1.00(p<0.001$, Figure 10c). 


\subsubsection{Cell Cycle Analysis}

To explore the effects of UA, UBA, and UBE on cell cycle distribution on blood cell cultures, the DNA content was evaluated. Propidium iodide/RNase A staining was performed using flow cytometry analyses for DNA content (Figure 11A-C).

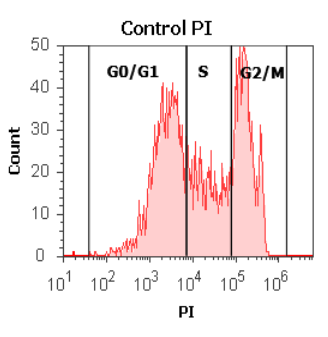

A.

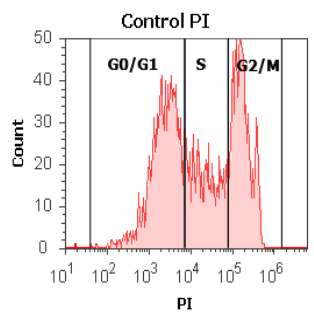

(a)

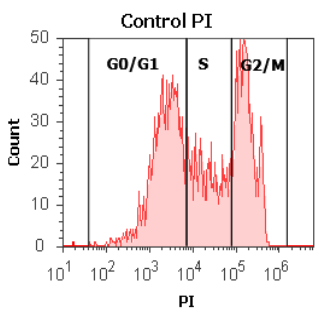

C.

(a)

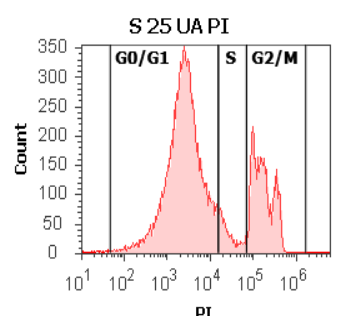

(b)

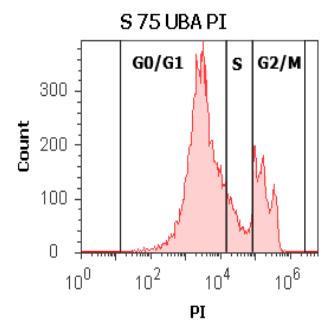

(b)

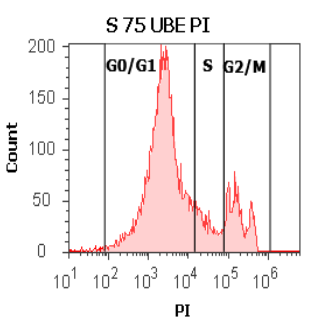

(b)

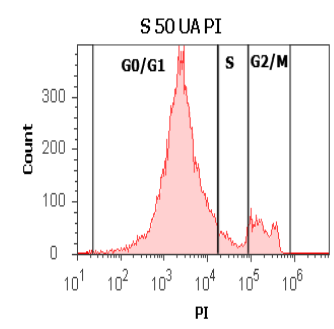

(c)

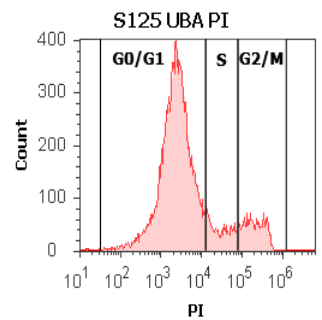

(c)

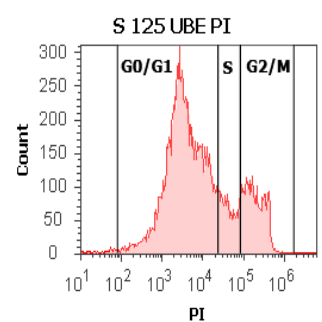

(c)

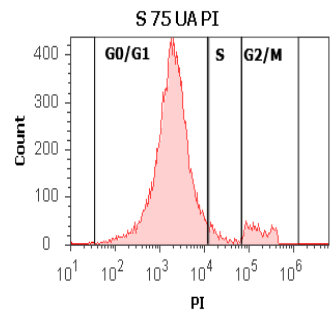

(d)

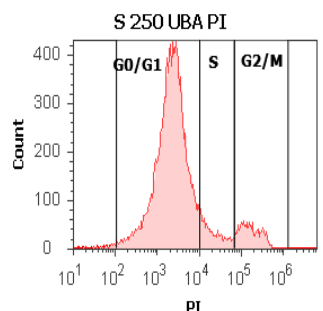

(d)

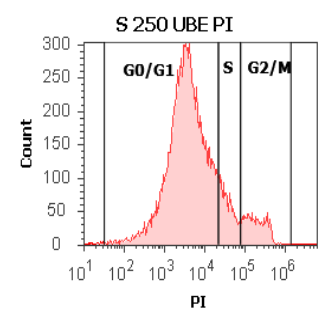

(d)

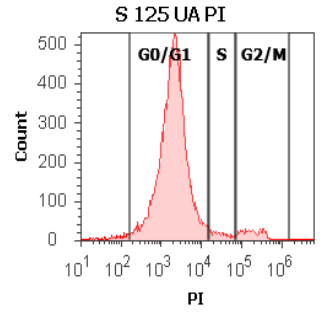

(e)

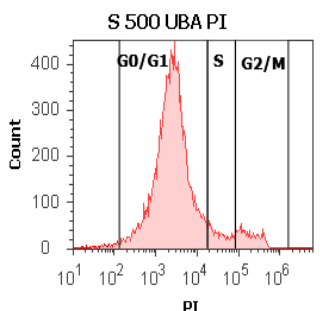

(e)

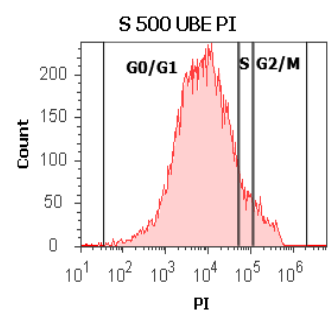

(e)

Figure 11. Cell cycle model of UA, UBA, and UBE treatments in normal blood cell cultures. PI/RNase A patterns of UA 25, 50, 75, $125 \mu \mathrm{g} / \mathrm{mL} \mathrm{A}(\mathbf{b}-\mathbf{e}) ; \mathbf{B}(\mathbf{b}-\mathbf{e})$ UBA 75, 125, 250, $500 \mu \mathrm{g} / \mathrm{mL} ; \mathbf{C}(\mathbf{b}-\mathbf{e})$ UBE 75, 125, 250, $500 \mu \mathrm{g} / \mathrm{mL}$ reported to 1\% DMSO (Negative Control, A(a), B(a), C(a)).

As shown in Figure 11A(a-e) and Figure 12a, UA concentrations of 25, 50, 75, and $125 \mu \mathrm{g} / \mathrm{mL}$ induce a noteworthy cell cycle arrest in the G1/G0 phase: $64.13 \pm 1.55 \%$; $78.52 \pm 0.87 \% ; 81.91 \pm 1.41 \% ; 88.09 \pm 0.98 \%$ vs. $39.29 \pm 0.76 \% ; p<0.01, p<0.001$ compared to solvent control. This activity is directly proportional to UA concentrations.

To understand whether the cell growth inhibition was due to cell cycle arrest, blood cells were treated with UBA of 75-500 $\mu \mathrm{g} / \mathrm{mL}$ concentrations (Figure 11B(a-e)). U. barbata dry extracts exhibited a noticeable cell cycle arrest in G0/G1 phase reported to 1\% DMSO: $65.13 \pm 0.15 \% ; 76.35 \pm 0.94 \% ; 78.93 \pm 0.54 \% ; 81.86 \pm 1.11 \% ;$ vs. $39.29 \pm 0.76 \%(p<0.01$, $p<0.001$, Figure 12b).

Thereby, 75, 125, 250, and $500 \mu \mathrm{g} / \mathrm{mL}$ of UBE (Figure $11 \mathrm{C}(\mathrm{a}-\mathrm{e})$ ) induced cell cycle arrest in G0/G1 phase reported to the negative control as follows: $68.16 \pm 0.14 \% ; 68.47 \pm 0.58 \%$; $76.06 \pm 0.68 \% ; 82.75 \pm 0.55 \%$ vs. $39.29 \pm 0.76 \%$ ( $p<0.001$, Figure $12 c)$.

Finally, it can be observed that UA proved the highest effect on cell cycle arrest in G0/G1, followed by UBA and UBE with similar activities. 
In this study, we observed that the lowest concentration $(25 \mu \mathrm{g} / \mathrm{mL})$ of UA determined an increase of DNA synthesis (Figure 13A $(\mathrm{a}, \mathrm{b}))$ in comparison with 1\% DMSO $(17.25 \pm$ $0.36 \%$ vs. $11.43 \pm 1.04 \%, p<0.05$, Figure $14 a)$.

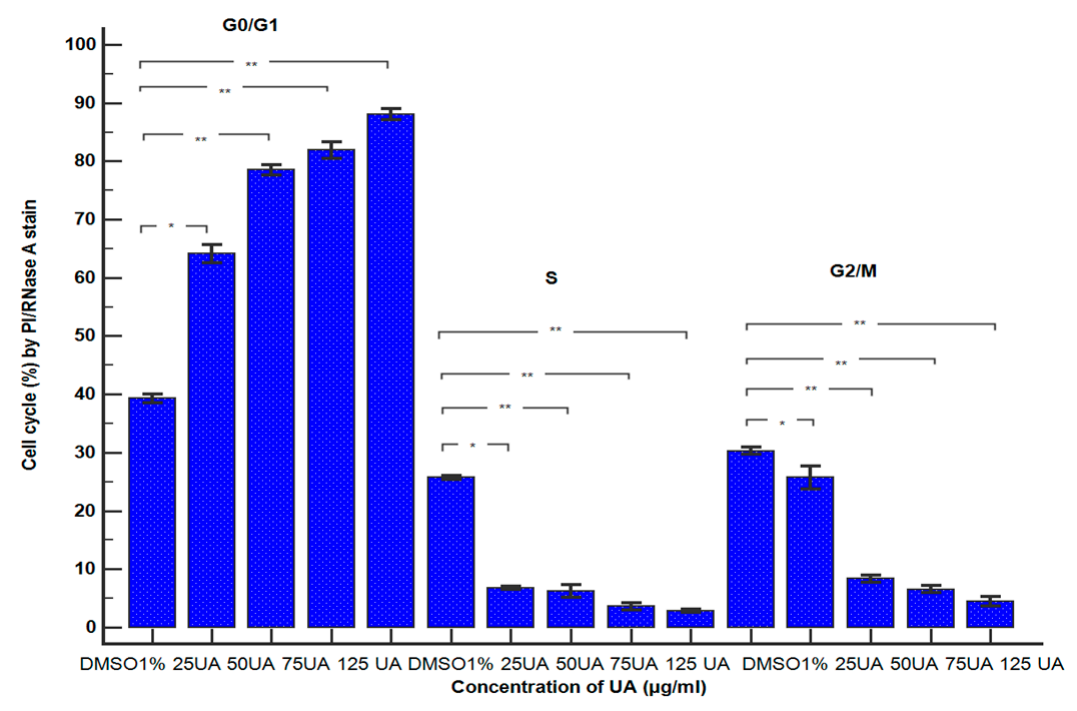

(a)

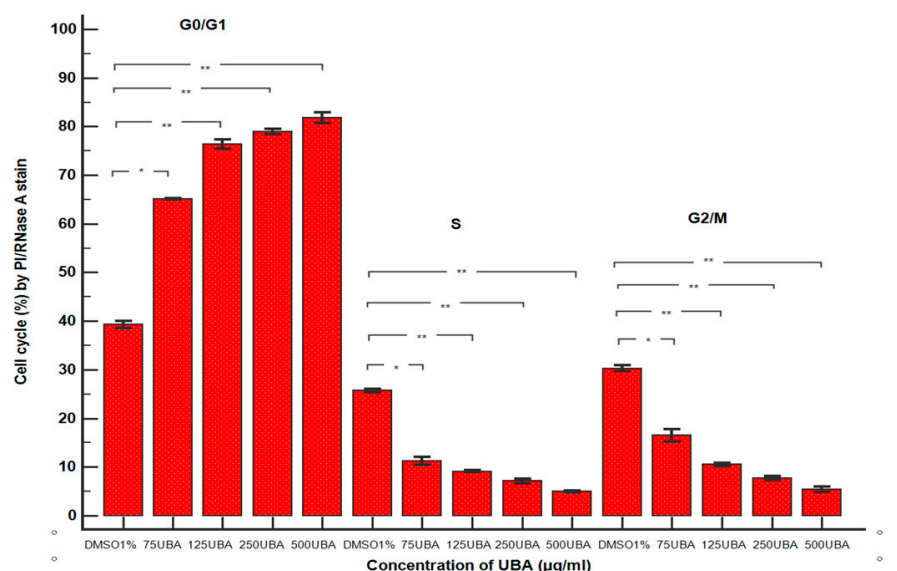

(b)

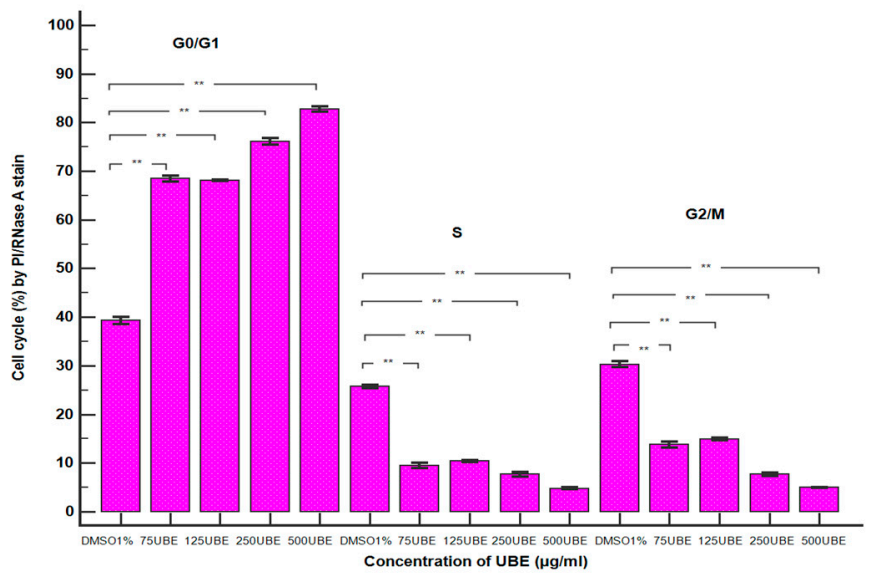

(c)

Figure 12. Statistical analysis of DNA content: (a) UA; (b) UBA; (c) UBE. ${ }^{*} p<0.01$, and ${ }^{* *} p<0.001$ represent significant statistical differences between control and samples made by paired samples $t$-test.

\subsubsection{Cell Proliferation Assay}

Flow cytometry analyses with EdU incorporation were used for examining DNA synthesis in blood cells (Figure 13).

Instead, UA at 50, 75 and $125 \mu \mathrm{g} / \mathrm{mL}$ did not significantly alter DNA synthesis (Figure $13 \mathrm{~A}(\mathrm{a}, \mathrm{c}-\mathrm{e}))$ relative to the control $(11.25 \pm 0.83 \% ; 10.32 \pm 0.64 \% ; 6.49 \pm 1.25 \%$ vs. $11.43 \pm 1.04 \%, p \geq 0.05$, Figure 14a).

The lowest concentration of UBA $(75 \mu \mathrm{g} / \mathrm{mL})$ did not significantly modify the DNA synthesis (Figure 13B $(\mathrm{a}, \mathrm{b})$ ) more than $1 \%$ DMSO: $12.78 \pm 0.67 \%$ vs. $11.43 \pm 1.04 \%(p \geq 0.05$, Figure 14b). 


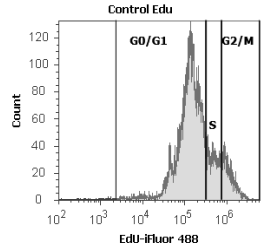

A.

(a)

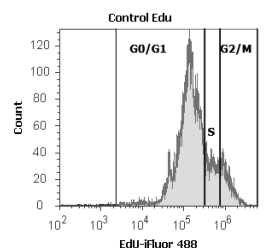

(a)

B.

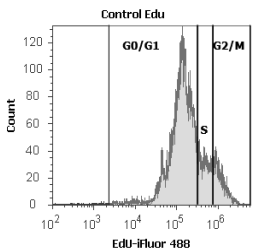

C.

(a)

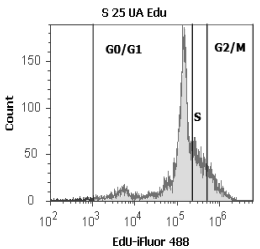

(b)

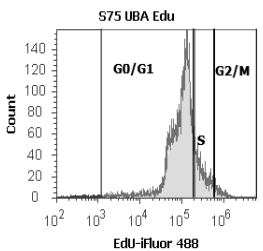

(b)

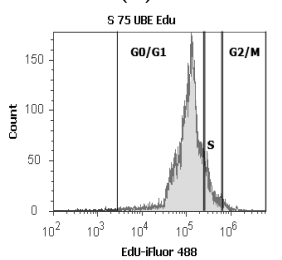

(b)

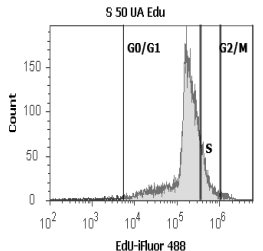

(c)

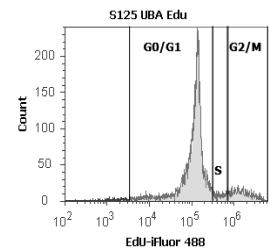

(c)

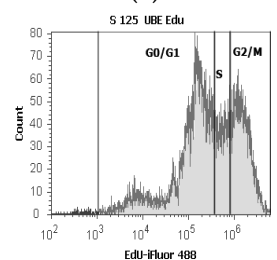

(c)

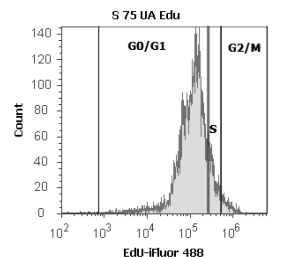

(d)

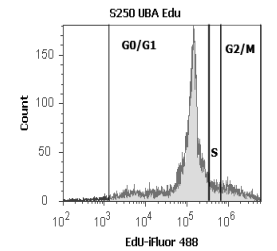

(d)

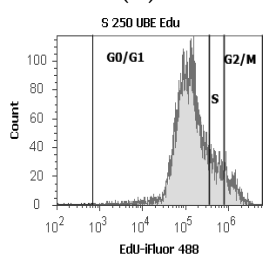

(d)

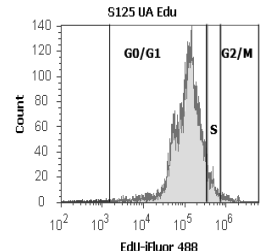

(e)

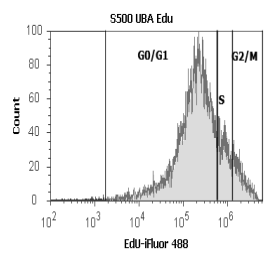

(e)

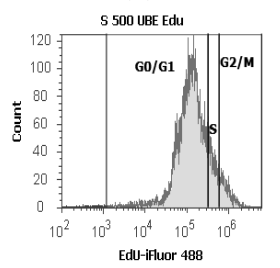

(e)

Figure 13. Cell proliferation status of UA, UBA, and UBE treatments in normal blood cell cultures. EdU-iFluor 488 patterns of UA 25, 50, 75, $125 \mu \mathrm{g} / \mathrm{mL}(\mathbf{A}(\mathbf{b}-\mathbf{e})) ;(\mathbf{B}(\mathbf{b}-\mathbf{e}))$ UBA 75, 125, 250, $500 \mu \mathrm{g} / \mathrm{mL} ;(\mathbf{C}(\mathbf{b}-\mathbf{e})) \mathrm{UBE} 75,125,250,500 \mu \mathrm{g} / \mathrm{mL}$ reported to $1 \% \operatorname{DMSO}(\mathbf{A}(\mathbf{a}), \mathbf{B}(\mathbf{a}), \mathbf{C}(\mathbf{a}))$.

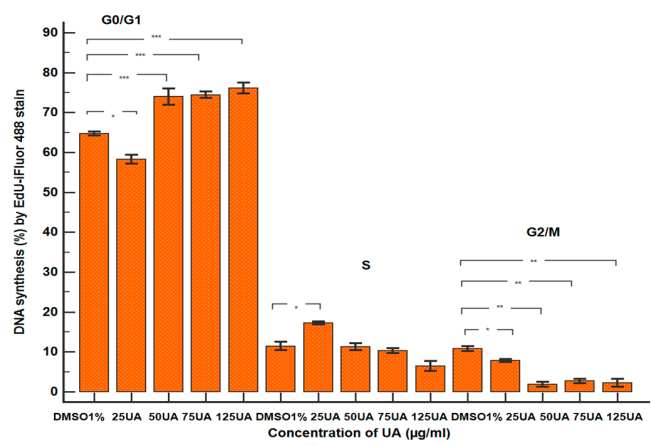

(a)

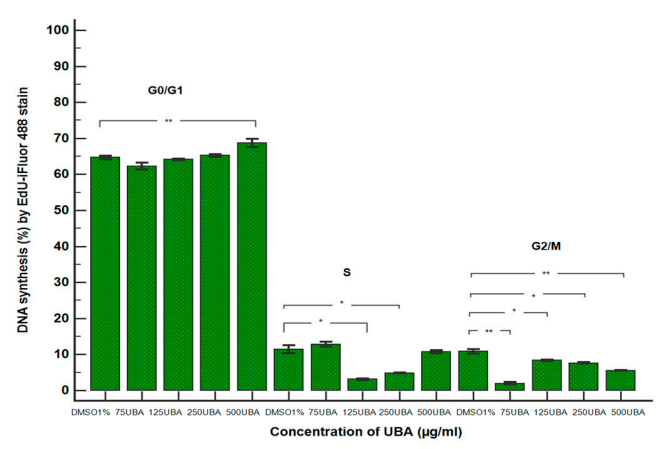

(b)

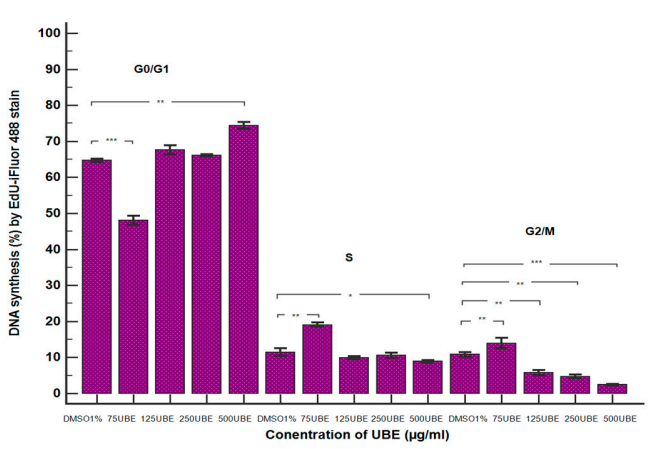

(c)

Figure 14. Statistical analysis of DNA synthesis: (a) UA; (b) UBA; (c) UBE. ${ }^{*} p<0.05,{ }^{* *} p<0.01$, and ${ }^{* * *} p \leq 0.001$ represent significant statistical differences between the control and samples made by paired samples $t$-test. 
Regarding higher concentrations of UBA (125 and $250 \mu \mathrm{g} / \mathrm{mL}$ ), a decrease of DNA synthesis (Figure $13 \mathrm{~B}(\mathrm{a}, \mathrm{c}, \mathrm{d})$ ) was registered, compared with $1 \%$ DMSO, with moderate differences: $3.12 \pm 0.18 \% ; 4.81 \pm 0.15 \%$ vs. $11.43 \pm 1.04 \%(p<0.05$, Figure $14 b)$.

Finally, the highest UBA concentration $(500 \mu \mathrm{g} / \mathrm{mL})$ did not significantly affect DNA synthesis (Figure $13 \mathrm{~B}(\mathrm{a}, \mathrm{e})$ ) more than the solvent control: $10.77 \pm 0.43 \%$ vs. $11.43 \pm 1.04 \%$ $(p \geq 0.05$, Figure $14 b)$.

In blood cells treated with $75 \mu \mathrm{g} / \mathrm{mL} \mathrm{UBE}$, an evident higher stimulation of DNA synthesis reported to solvent control $(19.05 \pm 0.64 \%$ vs. $11.43 \pm 1.04 \%, p<0.01)$ was registered (Figure 13C $(\mathrm{a}, \mathrm{b})$ and Figure $14 \mathrm{c})$.

The treatment with 125 and $250 \mu \mathrm{g} / \mathrm{mL}$ of UBE (Figure 13a,d) did not significantly alter DNA synthesis in comparison with 1\% DMSO: $9.92 \pm 0.43 \% ; 10.60 \pm 0.63 \%$ vs. $11.43 \pm 1.04 \%,(p \geq 0.05$, Figure $14 c)$.

Furthermore, $500 \mu \mathrm{g} / \mathrm{mL}$ of UBE produced a lower DNA synthesis stimulation (Figure $13 \mathrm{C}(\mathrm{a}, \mathrm{e})$ ) than the negative control: $8.89 \pm 0.30 \%$ vs. $11.43 \pm 1.04 \%(p<0.05$, Figure 14c).

\section{Discussion}

Our previous study analyzed five $U$. barbata dry extracts in different solvents [13]; we calculated the yield and evaluated the usnic acid, total polyphenols, and tannins content of each obtained extract. Therefore, we opted only for three lichen dry extracts for the present study: in ethyl acetate, acetone, and ethanol.

The highest usnic acid content $(376.73 \mu \mathrm{g} / \mathrm{mg}$ ) was the reason for selecting UBEA in the first phase of our study-usnic acid isolation. Then, isolated usnic acid was purified in the sample matrix. As a result, we obtained usnic acid with $89.36 \%$ purity and a yield of $28.15 \%$. Ranković et al. (2012) obtained $95 \mathrm{mg}$ usnic acid with $98.6 \%$ purity from $500 \mathrm{mg}$ $U$. barbata dry acetone extract [59]. The purity value difference could be due to the solvents used. We used only DMSO, while in the previously mentioned study, dry acetone extract was dissolved in benzene and then, usnic acid was recrystallized using chloroform/ethanol. We can state that our isolated usnic acid is (+)-UA because Usnea sp. tends to produce this enantiomer exclusively; in addition, (+)-UA registers antiviral, insecticidal, and phytotoxic activities significantly higher than (-)-UA [69].

Isolated UA and both UBA and UBE were used to evaluate their cytotoxic activity on blood cells. We opted for UBA because it contains an appreciable usnic acid amount $(282.78 \mu \mathrm{g} / \mathrm{mg})$ and other secondary metabolites. In addition, only $127.21 \mu \mathrm{g} / \mathrm{mg}$ of UA were extracted in UBE and a wider lichen secondary metabolites variety. UBE also had the highest extraction yield (12.52\%) compared with UBA (6.36\%) and UBEA (6.27\%) [13]. Consequently, the obtained biological effects could be correlated with the secondary metabolites content.

The present study proved that UA generally induced a significant cytotoxic effect on normal blood cells, more intense than both $U$. barbata extracts, UBA, and UBE. Hence, in early apoptosis events, the appearance of PS residues (commonly hidden within the plasma membrane) on the surface of the cells can be used to detect and measure this PCD. In our flow cytometry method, we opted for annexin $\mathrm{V}$ as staining to detect apoptotic cells due to its ability of PS-binding [70]. Moreover, translocation of PS to the external cell surface can occur during apoptosis and necrosis. The difference between these two forms of cell death is that the cell membrane remains intact in early apoptosis; however, it loses integrity and becomes permeable when necrosis is installed [71]. Shlomovitz et al. (2019) showed that PS externalization is also available in necroptosis [72]. However, in RBCs, this process corresponds to eryptosis (quasi-apoptosis) [73]. The intact cells membrane consists of the bilayer with choline-containing phospholipids (phosphatidylcholine and sphingomyelin) in the outer layer and amine-containing phospholipids (phosphatidylethanolamine and PS) in the inner layer. This normal disposition is known as phospholipid asymmetry. Lipid asymmetry is disturbed when the erythrocytes enter into eryptosis, and PS is exposed on RBCs surface [74]. This process involves three ATP and $\mathrm{Ca}^{2+}$-dependent transporters activation (flippase [75], floppase [76], and scramblase [77]). In addition, spectrin [78,79] 
oxidation and increasing cytoplasmic $\mathrm{Ca}^{2+}[80]$ concentration lead to membrane proteins denaturation [81]. Usnic acid oxidative stress-induced plays an essential role in all blood cells PCD, triggering these various molecular mechanisms [35]. One of the prominent protein families that regulate and execute programmed cell death is caspases; they cleave a subset of essential cellular proteins to promote apoptotic cell death [82].

In all blood cells types PCD involves caspases $[50,52,53,59,63,73,83-86]$. In response to apoptotic stress, the activated initiator caspases (caspase-2, 8, 9) cleave and activate the effector caspases (caspase-3, 6, 7), which execute the death process [87]. They regulate the extrinsic (receptor-mediated) apoptosis pathway involving receptor binding, followed by activation of the initiator caspase, caspase-8, which activates caspase- 3 or amplifies caspase-3 activation cleaving BH3 Interacting Domain Death Agonist protein. Bid cleavage induces mitochondrial cytochrome $c$ release, forming a protein complex (apoptosome) and activating caspase-9 [88]. During apoptosis, caspase-3 is also actively transported to the nucleus through the nuclear pores, playing a significant role in its disintegration by processing several nuclear substrates. Caspase-7 plays a significant role in cell viability loss [89]. According to Sundquist et al. (2006), the late apoptotic events occur after activating the effector caspases. Late apoptosis includes exposure of phosphatidylserine on the external surface of the plasma membrane (which can be measured by annexin $\mathrm{V}$ binding), cleavage of poly (ADP-ribose) polymerase (PARP), and internucleosomal DNA fragmentation [48]. McComb et al. (2019) revealed that efficient apoptosis requires feedback amplification of upstream apoptotic signals by effector caspase- 3 or -7 [90]. For this reason, we aimed to evaluate the influence of our tested samples on caspase $3 / 7$ apoptosis pathway. The obtained results showed that caspase $3 / 7$ activity was significantly stimulated during PCD process.

During apoptosis, caspase-3 is actively transported to the nucleus through the nuclear pores, playing a significant role in its disintegration by processing several nuclear substrates [89]. Nuclear apoptosis is characterized by chromatin condensation and progressive DNA cleavage into high-molecular-weight fragments and oligo-nucleosomes [91]. We analyzed the nuclear shrinkage to validate that UA, UBA, and UBE caused apoptosis; this process occurs only in white blood cells [92], RBCs, and platelets being enucleate. Chromatin condensation and fragmentation of nuclei are included in PCD [93]; exclusively, UA at high concentrations showed an appreciable stimulatory effect compared with the solvent control and UBA, and UBE samples.

Various studies have recently shown that lysosomes have been implicated in the regulation of cell death. Increasing their membrane permeability, released hydrolytic enzymes can contact cytosolic targets and contribute to apoptotic cell death [94]. Furthermore, lysosomal activity is directly associated with autophagy, another decisive process for cell death [95]. Various studies from accessed scientific literature analyze autophagy in platelets [96,97] and different WBCs [98-100].

Moreover, according to numerous studies, mitochondrial dysfunction consists of structural alteration, membrane potential disruption, and electron transport reaction instability. These events generate ROS overproduction, caspase cascades activation, and apoptosis pathway initiation [101]. The mitochondrial apoptotic pathway is available only at platelets [102,103], and WBCs [104].

In addition, low ROS concentration can promote cell proliferation, whereas excessive ROS levels cause DNA oxidative damage, consequently inducing cell death [105]. ROS levels are implicated in all blood cell lines death: platelets [106,107], RBCs [108,109], and WBCs $[110,111]$.

It is known that the cell cycle consists of few successive phases in mammals: synthesis (S) with DNA replication and mitosis $(\mathrm{M})$ with repartition of replicated DNA into two daughter cells. Separation of DNA replication from mitosis is performed by two gap phases (G1 and G2). In G1, the cell increasing size, RNA, and protein synthesis occurs, while in G2, after DNA synthesis, the cell grows and synthesizes proteins. Only in RBCs cell cycle arrest occurs in G1 [112]. After division, the cell enters the resting phase, known as the G0 
gap phase [113]. Thus, cell cycle arrest represents the first response to DNA damage and one of the first steps in cell apoptosis. However, nucleate WBCs proliferation is a tightly controlled process, and DNA replication is essential [114].

According to the obtained results, the high ROS levels produced by 75 and $125 \mu \mathrm{g} / \mathrm{mL}$ of UA in blood cells triggers a series of consecutive events: cell apoptosis, effector caspases 3/7 activation, pyknosis, autophagy, and cell-cycle arrest in the G0/G1 phase. Furthermore, many studies on numerous cell types proved apoptosis induction by ROS [115].

We have also shown that 125,250 , and $500 \mu \mathrm{g} / \mathrm{mL}$ concentrations of UBA and UBE triggered blood cells apoptosis by caspase $3 / 7$ pathway, oxidative stress, and accumulation of cells in G0/G1. Moreover, altered cell-cycle checkpoints and cell apoptosis parameters conformed with references [116].

Our results proved that UA and UBE at the lowest concentrations stimulated DNA replication (S-phase of the cell cycle). At higher concentrations, they highlighted inhibitory activity on blood cell proliferation. In great measure, these opposite effects manifested at low and high concentrations and can be associated with ROS levels, as previously mentioned. Similar data are mentioned by Damiano et al. (2019), revealing ROS dual function in skeletal muscle: at low levels, they improve muscle force and adaptation to exercise, while at high levels, they decrease muscle performance [117].

However, relatively few studies from the accessed scientific literature are focused exclusively on proving the effects of Usnea sp. extracts and usnic acid on normal cells [60,118]. A few years ago, dietary supplements containing usnic acid used for weight loss (Lipokinetix, [119]) reported severe hepatotoxic effects [120-122]. Fujimoto et al. (2010) reported that in vitro usnic acid hepatotoxicity involves oxidative stress, mitochondrial toxicant depletion of glycogen [123], and potential ATP biosynthesis inhibition mediated by mitochondrial electron transport chain [124], triggering necrotic death of hepatocytes. The structural properties of usnic acid can explain these molecular mechanisms. Thus, usnic acid is a lipophilic compound that can easily pass the mitochondrial membranes into the matrix, releasing a proton. Next, usniate anion diffuses into the intermembrane space to bind to a proton to restore usnic acid. The resulting cycle causes a proton leak that could dissipate the proton grad across the membrane, altering ATP levels and changing mitochondrial membrane potential [125]. Usnic acid can induce structural changes in intracellular glutathione molecules, decreasing its reduced form (GSH) [126]. In the same mode, usnic acid can perform spectrin oxidation with cell membrane shrinkage and PS exposure during apoptosis. Thus, usnic acid prooxidant potential can induce oxidative stress and liver cell death signaling. Concomitantly, using natural or synthetic antioxidants to neutralize the prooxidative activity of UA might also be a cell-protecting measure. Due to high hepatotoxicity induced by usnic acid, FDA released a Safety Alerts for Human Medical Products about Lipokinetix [119]. This notification is also current and supports the necessity for identification of natural or synthetic compounds to ensure the safe use of AU as potential anticancer drug.

Instead, the most numerous researchers pointed out these activities on various tumor cell lines [127]. For instance, Ozturk et al. (2019) reported several extract types of different Usnea sp. which determine cell apoptosis and DNA damage on cancer cells [128]. In addition, methanol extracts of $U$. barbata induced cell apoptosis, as evidenced by the increasing Annexin V expression and pan-caspase activation in human breast and lung cancer cells [16]. Additionally, Disoma et al. (2018) mentioned caspase 3/7 activation as an apoptotic mechanism on colon cancer cells proved by $U$. filipendula extracts [129]. In their study, Koparal et al. (2006) examined usnic acid effects on two types of lung cells (normal and tumor cells). They described usnic acid cytotoxic activity on both cell types and highlighted that cancer cells are more sensitive than normal cells [130]. Geng et al. (2018) reported that usnic acid induces cycle arrest, apoptosis, and autophagy in gastric cancer cells types in vitro and in vivo [131]. In another study, Wang et al. (2019) proved antileukemia action of $(+)$ usnic acid derivatives, inhibiting pan-Pim kinases [116]. Besides, Rabelo et al. (2012) suggested that usnic acid displays variable redox-active 
properties, acting as an antioxidant and prooxidant agent, according to different system conditions and cellular environment [27]. High cytotoxic effects on cancer cells and minimal unwanted effects on normal cells represent the essential quality of an antitumor agent. High cytotoxicity levels on cancer cells and low damage on normal cells represent the meaningful purpose in antitumor activity. Finally, Tram et al. (2020) evidenced the highly different cytotoxicity of the same compound against tumor and normal cells [23].

Our study highlights the relationship between concentration and biological effect on normal blood cells. Thereby, usnic acid at a minimal concentration $(25 \mu \mathrm{g} / \mathrm{mL})$ shows low cytotoxicity on human blood cells, slowly inducing cell apoptosis, caspases $3 / 7$ activation, mild ROS level and stimulating DNA synthesis. On the other hand, higher concentrations $(50-125 \mu \mathrm{g} / \mathrm{mL})$ of UA progressively display significant cytotoxic effects: increasing cell apoptosis, effector caspases $3 / 7$ proapoptotic signal, nuclear condensation, autophagy, oxidative stress, and causing cell-cycle arrest in G1/G0 phase.

$U$. barbata dry extracts in acetone and ethanol, at low concentration $(75 \mu \mathrm{g} / \mathrm{mL})$, exhibit minor cytotoxicity, inducing cell and nuclear apoptosis, autophagy, and increased DNA synthesis. In contrast, higher concentrations $(125-500 \mu \mathrm{g} / \mathrm{mL})$ of UBA and UBE report directly proportional significant toxic effects on blood cells, enhancing cell and nuclear apoptosis, autophagy, ROS levels and promoting cell-cycle arrest G1/G0 phase.

\section{Conclusions}

The novelty of our study consists of analyzing $U$. barbata and usnic acid cytotoxic effects on human normal blood cells cultures. The principal points of this complex activity have been highlighted, exploring the cell and nuclear apoptosis, caspase 3/7 activity, autophagy, oxidative cellular stress, cell cycle, and DNA synthesis.

High cytotoxicity levels on cancer cells and relatively lower damage to the normal blood cells represent the meaningful purpose in antitumor activity. Based on this statement, our study can offer essential data to target the previously mentioned objective by evaluating the blood cells sensitivity to various concentrations of $U$. barbata dry extracts and usnic acid. The obtained results suggest that future researches may select several concentration domains to evaluate their various pharmacological activities. Moreover, exploring anticancer potential, we can select which extracts highlight optimal and exclusive cytotoxicity on a broad domain of cancer cells, also displaying minimal or no side effects on normal cells.

Supplementary Materials: The following are available online at https://www.mdpi.com/article/10.3 390/antiox10081171/s1: video S1 Isolated usnic acid.

Author Contributions: All authors contributed equally to this study and shared the first authorship. Conceptualization, V.P., E.M. and L.B.; methodology, E.M., L.B., T.C., D.R., I.E.C., software, E.M. and D.R.; validation, E.M., L.B. and D.R.; formal analysis, G.C.C. and M.A.; investigation, A.C.; resources, V.P.; data curation, G.C.C. and M.A.; writing-original draft preparation, V.P., E.M. and D.R.; writing - review and editing, V.P., E.M., G.V. and D.G.; visualization, G.C.C., G.V. and D.G.; supervision, L.B., G.C.C. and V.B.; project administration, V.B.; funding acquisition, V.P. All authors have read and agreed to the published version of the manuscript.

Funding: This work is supported by the project ANTREPRENORDOC, in the framework of Human Resources Development Operational Program 2014-2020, financed from the European Social Fund under the contract number 36355/23.05.2019 HRD OP/380/6/13-SMIS Code: 123847.

Institutional Review Board Statement: All aspects of ethics approval and consent of the patients to participate in this study are made in conformity with the declaration of Helsinki 2000, and are approved by the Ethics Committee of “Ovidius" University of Constanta, Romania, 7080/10.06.2021.

Informed Consent Statement: Informed consent was obtained from all subjects involved in the study.

Data Availability Statement: Data is contained within the article and supplementary material.

Acknowledgments: This study was performed in collaboration with the Center for Research and Development of the Morphological and Genetic Studies of Malignant Pathology (CEDMOG), “Ovid- 
ius" University of Constanta, 145 Tomis Blvd., 900591, Constanta, Romania, Research Centre of Instrumental Analysis SCIENT, 1E Petre Ispirescu Street, 77167, Tancabesti, Romania, and Institute of Biological Research Iasi, branch of NIRDBS, 47 Lascar Catargi Street, 700107 Iasi, Romania.

Conflicts of Interest: The authors declare no conflict of interest.

\section{References}

1. Atanasov, A.G.; Waltenberger, B.; Pferschy-Wenzig, E.M.; Linder, T.; Wawrosch, C.; Uhrin, P.; Temml, V.; Wang, L.; Schwaiger, S.; Heiss, E.H.; et al. Discovery and resupply of pharmacologically active plant-derived natural products: A review. Biotechnol. Adv. 2015, 33, 1582-1614. [CrossRef] [PubMed]

2. Mitrović, T.; Stamenković, S.; Cvetković, V.; Nikolić, M.; Tošić, S.; Stojičić, D. Lichens as source of versatile bioactive compounds. Biol. Nyssana 2011, 2, 1-6.

3. Mazid, M.; Khan, T.A.; Mohammad, F. Role of secondary metabolites in defense mechanisms of plants. Biol. Med. 2011, 3, 232-249.

4. Mukherjee, P.K.; Ponnusankar, S.; Venkatesh, P. Synergy in herbal medicinal products: Concept to realization. Indian J. Pharm. Educ. Res. 2011, 45, 210-217.

5. Lahlou, M. The Success of Natural Products in Drug Discovery. Pharmacol. Pharm. 2013, 4, 17-31. [CrossRef]

6. Veeresham, C. Natural products derived from plants as a source of drugs. J. Adv. Pharm. Technol. Res. 2012, 3, 200-201. [CrossRef]

7. Yin, J.; Li, Q.; Sun, L.D.; Yang, Q.; Zhao, Z.; Ran, Q.S.; Weng, X.G.; Chen, Y.; Wang, Y.J.; Li, Y.J.; et al. Research advancement in natural anti-cancer product. Zhongguo Zhong Yao Za Zhi 2019, 44, $19-27$.

8. $\quad$ Elkhateeb, W.A.; Daba, G.M.; Sheir, D.; Nguyen, T.-D.; Hapuarachchi, K.K.; Thomas, P.W. Mysterious World of Lichens: Highlights on Their History, Applications, and Pharmaceutical Potentials. Nat. Prod. J. 2020, 10, 1-13. [CrossRef]

9. Aschenbrenner, I.A.; Cernava, T.; Berg, G.; Grube, M. Understanding microbial multi-species symbioses. Front. Microbiol. 2016, 7, 180. [CrossRef]

10. Molnár, K.; Farkas, E. Current results on biological activities of lichen secondary metabolites: A review. Z. Nat. C 2010, 65, 157-173. [CrossRef]

11. Prateeksha; Paliya, B.S.; Bajpai, R.; Jadaun, V.; Kumar, J.; Kumar, S.; Upreti, D.K.; Singh, B.R.; Nayaka, S.; Joshi, Y.; et al. The genus Usnea: A potent phytomedicine with multifarious ethnobotany, phytochemistry and pharmacology. RSC Adv. 2016, 6, 21672-21696. [CrossRef]

12. Sepahvand, A.; Studzińska-Sroka, E.; Ramak, P.; Karimian, V. Usnea sp.: Antimicrobial potential, bioactive compounds, ethnopharmacological uses and other pharmacological properties; a review article. J. Ethnopharmacol. 2021, 268, 113656. [CrossRef] [PubMed]

13. Popovici, V.; Bucur, L.; Popescu, A.; Schröder, V.; Costache, T.; Rambu, D.; Cucolea, I.E.; Gîrd, C.E.; Caraiane, A.; Gherghel, D.; et al. Antioxidant and Cytotoxic Activities of Usnea barbata (L.) F.H. Wigg. Dry Extracts in Different Solvents. Plants 2021, 10, 909. [CrossRef]

14. Idamokoro, E.M.; Masika, P.J.; Muchenje, V.; Falta, D.; Green, E. In-vitro antibacterial sensitivity of Usnea barbata lichen extracted with methanol and ethyl-acetate against selected Staphylococcus species from milk of cows with mastitis. Arch. Anim. Breed. 2014, 57, 1-9. [CrossRef]

15. Engel, K.; Schmidt, U.; Reuter, J.; Weckesser, S.; Simon-Haarhaus, B.; Schempp, C.M. Usnea barbata extract prevents ultraviolet-B induced prostaglandin E2 synthesis and COX-2 expression in HaCaT keratinocytes. J. Photochem. Photobiol. B 2007, 89, 9-14. [CrossRef]

16. Zugic, A.; Jeremic, I.; Isakovic, A.; Arsic, I.; Savic, S.; Tadic, V. Evaluation of anticancer and antioxidant activity of a commercially available $\mathrm{CO}_{2}$ supercritical extract of old man's beard (Usnea barbata). PLoS ONE 2016, 11, e0146342. [CrossRef] [PubMed]

17. Popovici, V.; Bucur, L.A.; Schröder, V.; Gherghel, D.; Mihai, C.T.; Caraiane, A.; Badea, F.C.; Vochița, G.; Badea, V. Evaluation of the Cytotoxic Activity of the Usnea barbata (L.) F. H. Wigg Dry Extract. Molecules 2020, 25, 1865. [CrossRef]

18. Tang, J.Y.; Wu, K.H.; Wang, Y.Y.; Farooqi, A.A.; Huang, H.W.; Yuan, S.S.F.; Jian, R.I.; Tsao, L.Y.; Chen, P.A.; Chang, F.R.; et al. Methanol Extract of Usnea barbata Induces Cell Killing, Apoptosis, and DNA Damage against Oral Cancer Cells through Oxidative Stress. Antioxidants 2020, 9, 694. [CrossRef]

19. Ranković, B. Lichen Secondary Metabolites: Bioactive Properties and Pharmaceutical Potential; Springer International Publishing: Cham, Switzerland, 2015; pp. 1-29.

20. Pizarro, D.; Divakar, P.K.; Grewe, F.; Crespo, A.; Grande, F.D.; Lumbsch, H.T. Genome-wide analysis of biosynthetic gene cluster reveals correlated gene loss with absence of usnic acid in lichen-forming fungi. Genome Biol. Evol. 2020, 12, 1858-1868. [CrossRef]

21. Salgado, F.; Albornoz, L.; Cortéz, C.; Stashenko, E.; Urrea-Vallejo, K.; Nagles, E.; Galicia-Virviescas, C.; Cornejo, A.; Ardiles, A.; Simirgiotis, M.; et al. Secondary metabolite profiling of species of the genus usnea by UHPLC-ESI-OT-MS-MS. Molecules 2017, $23,54$. [CrossRef]

22. Mesta, A.R.; Rajeswari, N.; Kanivebagilu, V.S. Distribution of bioactive compounds in usneoid lichens from Western Ghats. Plant Arch. 2019, 19, 2163-2168.

23. Tram, N.T.T.; Anh, D.H.; Thuc, H.H.; Tuan, N.T. Investigation of chemical constituents and cytotoxic activity of the lichen Usnea undulata. Vietnam J. Chem. 2020, 58, 63-66. [CrossRef]

24. Alahmadi, A.A. Usnic acid biological activity: History, evaluation and usage. Int. J. Basic Clin. Pharmacol. 2017, 6, 2752-2759. [CrossRef] 
25. White, P.A.S.; Oliveira, R.C.M.; Oliveira, A.P.; Serafini, M.R.; Araújo, A.A.S.; Gelain, D.P.; Moreira, J.C.F.; Almeida, J.R.G.S.; Quintans, J.S.S.; Quintans-Junior, L.J.; et al. Antioxidant Activity and Mechanisms of Action of Natural Compounds Isolated from Lichens: A Systematic Review. Molecules 2014, 19, 14496-14527. [CrossRef]

26. Leandro, L.F.; Munari, C.C.; Sato, V.L.; Alves, J.M.; de Oliveira, P.F.; Mastrocola, D.F.; Martins Sde, P.; Moraes Tda, S.; de Oliveira, A.I.; Tozatti, M.G.; et al. Assessment of the genotoxicity and antigenotoxicity of (+)-usnic acid in V79 cells and Swiss mice by the micronucleus and comet assays. Mutat Res. 2013, 753, 101-106. [CrossRef]

27. Rabelo, T.K.; Zeidán-Chuliá, F.; Vasques, L.M.; dos Santos, J.P.A.; da Rocha, R.F.; de Bittencourt Pasquali, M.A.; Rybarczyk-Filho, J.L.; Araújo, A.A.S.; Moreira, J.C.F.; Gelain, D.P. Redox characterization of usnic acid and its cytotoxic effect on human neuron-like cells (SH-SY5Y). Toxicol. Vitr. 2012, 26, 304-314. [CrossRef] [PubMed]

28. Basiouni, S.; Fayed, M.A.A.; Tarabees, R.; El-Sayed, M.; Elkhatam, A.; Töllner, K.-R.; Hessel, M.; Geisberger, T.; Huber, C.; Eisenreich, W.; et al. Characterization of Sunflower Oil Extracts from the Lichen Usnea barbata. Metabolites 2020, 10, 353. [CrossRef]

29. Neff, G.W.; Rajender Reddy, K.; Durazo, F.A.; Meyer, D.; Marrero, R.; Kaplowitz, N. Severe hepatotoxicity associated with the use of weight loss diet supplements containing ma huang or usnic acid. J. Hepatol. 2004, 6, 1062-1064. [CrossRef] [PubMed]

30. Moreira, C.T.; Oliveira, A.L.; Comar, J.F.; Peralta, R.M.; Bracht, A. Harmful effects of usnic acid on hepatic metabolism. Chem. Biol. Interact. 2013, 203, 502-511. [CrossRef]

31. Kartsev, V.; Lichitsky, B.; Geronikaki, A.; Petrou, A.; Smiljkovic, M.; Kostic, M.; Radanovic, O.; Soković, M. Design, synthesis and antimicrobial activity of usnic acid derivatives. Med. Chem. Comm. 2018, 9, 870-882. [CrossRef]

32. Cetin, H.; Tufan-Cetin, O.; Turk, A.O.; Tay, T.; Candan, M.; Yanikoglu, A.; Sumbul, H. Insecticidal activity of major lichen compounds, (-)- and (+)-usnic acid, against the larvae of house mosquito, Culex pipiens L. Parasitol. Res. 2008, 102, 1277-1279. [CrossRef] [PubMed]

33. Cakmak, K.C.; Gülçin, İ. Anticholinergic and antioxidant activities of usnic acid-an activity-structure insight. Toxicol. Rep. 2019, 6, 1273-1280. [CrossRef] [PubMed]

34. Odabasoglu, F.; Cakir, A.; Suleyman, H.; Aslan, A.; Bayir, Y.; Halici, M.; Kazaz, C. Gastroprotective and antioxidant effects of usnic acid on indomethacin-induced gastric ulcer in rats. J. Ethnopharmacol. 2006, 103, 59-65. [CrossRef] [PubMed]

35. Kohlhardt-Floehr, C.; Boehm, F.; Troppens, S.; Lademann, J.; Truscott, T.G. Prooxidant and antioxidant behaviour of usnic acid from lichens under UVB-light irradiation—Studies on human cells. J. Photochem. Photobiol. B Biol. 2010, 101, 97-102. [CrossRef] [PubMed]

36. Prokopiev, I.A.; Filippov, E.V.; Filippova, G.V.; Zhanataev, A.K. Pro/Antigenotoxic Activity of Usnic Acid Enantiomers In vitro. Bull. Exp. Biol. Med. 2018, 164, 312-315. [CrossRef] [PubMed]

37. Prokopiev, I.; Filippova, G.; Filippov, E.; Voronov, I.; Sleptsov, I.; Zhanataev, A. Genotoxicity of (+)- and (-)-usnic acid in mice. Mutat. Res. Genet. Toxicol. Environ. Mutagen. 2019, 839, 36-39. [CrossRef]

38. Silva, C.R.; Marinho, K.S.N.; Silva, T.D.S.; Ferreira, D.K.S.; Aguiar, G.M.; Martins, M.C.B.; Santos, K.R.P.; Aguiar Júnior, F.C.A.; Santos, N.P.S.; Pereira, E.C.; et al. Teratogenic Effect of Usnic Acid from Cladonia substellata Vainio during Organogenesis. BioMed Res. Int. 2017, 2017, 5948936. [CrossRef]

39. Erfani, S.; Valadbeigi, T.; Aboutaleb, N.; Karimi, N.; Moghimi, A.; Khaksari, M. Usnic acid improves memory impairment after cerebral ischemia/ reperfusion injuries by anti-neuroinflammatory, anti-oxidant, and anti-apoptotic properties. Iran. J. Basic Med. Sci. 2020, 23, 1225-1231.

40. Okuyama, E.; Umeyama, K.; Yamazaki, M.; Kinoshita, Y.; Yamamoto, Y. Usnic acid and diffractaic acid as analgesic and antipyretic components of Usnea diffracta. Planta Med. 1995, 61, 113-115. [CrossRef]

41. Machado, N.M.; de Rezende, A.A.A.; Nepomuceno, J.C.; Tavares, D.C.; Cunha, W.R.; Spanó, M.A. Evaluation of mutagenic, recombinogenic and carcinogenic potential of (+)-usnic acid in somatic cells of Drosophila melanogaster. Food Chem. Toxicol. 2016, 96, 226-233. [CrossRef]

42. Einarsdóttir, E.; Groeneweg, J.; Björnsdóttir, G.G.; Haroardottir, G.; Omarsdóttir, S.; Ingólfsdóttir, K.; Ögmundsdóttir, H.M. Cellular mechanisms of the anticancer effects of the lichen compound usnic acid. Planta Med. 2010, 76, 969-974. [CrossRef]

43. Kwong, S.P.; Wang, C. Review: Usnic acid-induced hepatotoxicity and cell death. Environ. Toxicol. Pharmacol. 2020, 80, 103493. [CrossRef] [PubMed]

44. Solárová, Z.; Liskova, A.; Samec, M.; Kubatka, P.; Büsselberg, D.; Solár, P. Anticancer Potential of Lichens' Secondary Metabolites. Biomolecules 2020, 10, 87. [CrossRef]

45. Galluzzi, L.; Vitale, I.; Aaronson, S.A.; Abrams, J.M.; Adam, D.; Agostinis, P.; Alnemri, E.S.; Altucci, L.; Amelio, I.; Andrews, D.W.; et al. Molecular mechanisms of cell death: Recommendations of the Nomenclature Committee on Cell Death 2018. Cell Death Differ. 2018, 25, 486-541. [CrossRef]

46. Wong, R.S.Y. Apoptosis in cancer: From pathogenesis to treatment. J. Exp. Clin. Cancer Res. 2011, 30, 87. [CrossRef] [PubMed]

47. Li, J.; Yuan, J. Caspases in apoptosis and beyond. Oncogene 2008, 27, 6194-6206. [CrossRef]

48. Sundquist, T.; Moravec, R.; Niles, A.; O’Brien, M.; Riss, T. Timing your apoptosis assays. Cell Notes 2006, 16, 18-21.

49. Melchinger, H.; Jain, K.; Tyagi, T.; Hwa, J. Role of Platel et Mitochondria: Life in a Nucleus-Free Zone. Front. Cardiovasc. Med. 2019, 6, 153. [CrossRef]

50. Leytin, V. Apoptosis in the anucleate platelet. Blood Rev. 2012, 26, 51-63. [CrossRef]

51. Nguyen, K.A.; Hamzeh-Cognasse, H.; Palle, S.; Anselme-Bertrand, I.; Arthaud, C.A.; Chavarin, P.; Pozzetto, B.; Garraud, O.; Cognasse, F. Role of siglec-7 in apoptosis in human platelets. PLoS ONE 2014, 9, e10623. [CrossRef] 
52. Berg, C.P.; Engels, I.H.; Rothbart, A.; Lauber, K.; Renz, A.; Schlosser, S.F.; Schulze-Osthoff, K.; Wesselborg, S. Human mature red blood cells express caspase-3 and caspase-8, but are devoid of mitochondrial regulators of apoptosis. Cell Death Differ. 2001, 8, 1197-1206. [CrossRef]

53. Bratosin, D.; Tcacenco, L.; Sidoroff, M.; Cotoraci, C.; Slomianny, C.; Estaquier, J.; Montreuil, J. Active caspases-8 and -3 in circulating human erythrocytes purified on immobilized annexin-V: A cytometric demonstration. Cytom. Part A 2009, 75A, 236-244. [CrossRef]

54. Holcik, M. Do mature red blood cells die by apoptosis? Trends Genet. 2002, 18, 121. [CrossRef]

55. Peter, M.E.; Krammer, P.H. The CD95(APO-1/Fas) DISC and beyond. Cell Death Differ. 2003, 10, 26-35. [CrossRef] [PubMed]

56. Mita, E.; Hayashi, N. Molecular biology of Fas antigen-Fas ligand system. Nippon Rinsho 1996, 54, $1736-1740$.

57. Lang, E.; Pozdeev, V.I.; Xu, H.C.; Shinde, P.V.; Behnke, K.; Hamdam, J.M.; Lehnert, E.; Scharf, R.E.; Lang, F.; Häussinger, D.; et al. Storage of erythrocytes induces suicidal erythrocyte death. Cell. Physiol. Biochem. 2016, 39, 668-676. [CrossRef]

58. Vaschenko, V.I.; Vil'yaninov, V.N. Eryptosis (quasi-apoptosis) the human red blood cells. Its role in medicinal therapy. Rev. Clin. Pharmacol. Drug Ther. 2019, 17, 5-38. [CrossRef]

59. Klatt, C.; Krüger, I.; Zey, S.; Krott, K.J.; Spelleken, M.; Gowert, N.S.; Oberhuber, A.; Pfaff, L.; Lückstädt, W.; Jurk, K.; et al. Platelet-RBC interaction mediated by FasL/FasR induces procoagulant activity important for thrombosis. J. Clin. Investig. 2018, 128, 3906-3925. [CrossRef] [PubMed]

60. Pretorius, E.; Du Plooy, J.N.; Bester, J. A Comprehensive Review on Eryptosis. Cell. Physiol. Biochem. 2016, 39, 1977-2000. [CrossRef]

61. Restivo, I.; Attanzio, A.; Tesoriere, L.; Allegra, M. Suicidal erythrocyte death in metabolic syndrome. Antioxidants 2021, 10, 154. [CrossRef]

62. Lang, E.; Lang, F. Triggers, inhibitors, mechanisms, and significance of eryptosis: The suicidal erythrocyte death. Biomed. Res. Int. 2015, 2015, 513518. [CrossRef] [PubMed]

63. Parihar, A.; Eubank, T.D.; Doseff, A.I. Monocytes and macrophages regulate immunity through dynamic networks of survival and cell death. J. Innate Immun. 2010, 2, 204-215. [CrossRef]

64. Galanty, A.; Paśko, P.; Podolak, I.; Zagrodzki, P. Optimization of usnic acid extraction conditions using fractional factorial design. Lichenologist 2020, 52, 397-401. [CrossRef]

65. Ranković, B.; Kosanić, M.; Stanojković, T.; Vasiljević, P.; Manojlović, N. Biological Activities of Toninia candida and Usnea barbata Together with Their Norstictic Acid and Usnic Acid Constituents. Int. J. Mol. Sci. 2012, 13, 14707-14722. [CrossRef]

66. Guo, L.; Shi, Q.; Fang, J.L.; Mei, N.; Ali, A.A.; Lewis, S.M.; Leakey, J.E.; Frankos, V.H. Review of usnic acid and Usnea barbata toxicity. J. Environ. Sci. Health C Environ. Carcinog Ecotoxicol. Rev. 2008, 26, 317-338. [CrossRef] [PubMed]

67. Matei, E.; Aschie, M.; Mitroi, A.F.; Ghinea, M.M.; Gheorghe, E.; Petcu, L.; Dobrin, N.; Chisoi, A.; Manea, M. Biomarkers involved in evaluation of platelets function in South-Eastern Romanian patients with hematological malignancies subtypes. Medicine 2021, 100, e25944. [CrossRef]

68. Gibson, M.G.; Miller, R.G. Beyond ANOVA: Basics of Applied Statistics. J. R. Stat. Soc. Ser. D Stat. 1986, 35, 566-567. [CrossRef]

69. Galanty, A.; Paśko, P.; Podolak, I. Enantioselective activity of usnic acid: A comprehensive review and future perspectives. Phytochem. Rev. 2019, 18, 527-548. [CrossRef]

70. Van Engeland, M.; Nieland, L.J.W.; Ramaekers, F.C.S.; Schutte, B.; Reutelingsperger, C.P.M. Annexin V-affinity assay: A review on an apoptosis detection system based on phosphatidylserine exposure. Cytometry 1998, 31, 1-9. [CrossRef]

71. Vermes, I.; Haanen, C.; Steffens-Nakken, H.; Reutellingsperger, C. A novel assay for apoptosis Flow cytometric detection of phosphatidylserine expression on early apoptotic cells using fluorescein labelled Annexin V. J. Immunol. Methods 1995, 184, 39-51. [CrossRef]

72. Shlomovitz, I.; Speir, M.; Gerlic, M. Flipping the dogma-Phosphatidylserine in non-apoptotic cell death. Cell Commun. Signal. 2019, 17, 139. [CrossRef]

73. Gusev, G.P.; Govekar, R.; Gadewal, N.; Agalakova, N.I. Understanding quasi-apoptosis of the most numerous enucleated components of blood needs detailed molecular autopsy. Ageing Res. Rev. 2017, 35, 46-62. [CrossRef]

74. Sathi, A.; Viswanad, V.; Aneesh, T.P.; Kumar, B.A. Pros and cons of phospholipid asymmetry in erythrocytes. J. Pharm. Bioallied Sci. 2014, 6, 81-85.

75. Jing, W.; Yabas, M.; Bröer, A.; Coupland, L.; Gardiner, E.E.; Enders, A.; Bröer, S. Calpain cleaves phospholipid flippase ATP8A1 during apoptosis in platelets. Blood Adv. 2019, 3, 219-229. [CrossRef]

76. Groen, A.; Romero, M.R.; Kunne, C.; Hoosdally, S.J.; Dixon, P.H.; Wooding, C.; Williamson, C.; Seppen, J.; Van Den Oever, K.; Mok, K.S.; et al. Complementary functions of the flippase ATP8B1 and the floppase ABCB4 in maintaining canalicular membrane integrity. Gastroenterology 2011, 141, 1927-1937.e4. [CrossRef] [PubMed]

77. Williamson, P. Phospholipid Scramblases. Lipid Insights 2015, 8, 41-44. [CrossRef] [PubMed]

78. Djinovic-Carugo, K.; Gautel, M.; Ylänne, J.; Young, P. The spectrin repeat: A structural platform for cytoskeletal protein assemblies. FEBS Lett. 2002, 513, 119-123. [CrossRef]

79. Machnicka, B.; Grochowalska, R.; Bogusławska, D.M.; Sikorski, A.F.; Lecomte, M.C. Spectrin-based skeleton as an actor in cell signaling. Cell. Mol. Life Sci. 2012, 69, 191-201. [CrossRef] [PubMed] 
80. Bissinger, R.; Petkova-Kirova, P.; Mykhailova, O.; Oldenborg, P.A.; Novikova, E.; Donkor, D.A.; Dietz, T.; Bhuyan, A.A.M.; Sheffield, W.P.; Grau, M.; et al. Thrombospondin-1/CD47 signaling modulates transmembrane cation conductance, survival, and deformability of human red blood cells. Cell Commun. Signal. 2020, 18, 155. [CrossRef] [PubMed]

81. Fadok, V.A.; De Cathelineau, A.; Daleke, D.L.; Henson, P.M.; Bratton, D.L. Loss of phospholipid asymmetry and surface exposure of phosphatidylserine is required for phagocytosis of apoptotic cells by macrophages and fibroblasts. J. Biol. Chem. 2001, 276, 1071-1077. [CrossRef]

82. Robertson, J.D.; Orrenius, S.; Zhivotovsky, B. Review: Nuclear events in apoptosis. J. Struct. Biol. 2000, 129, 346-358. [CrossRef] [PubMed]

83. Gyulkhandanyan, A.V.; Allen, D.J.; Mykhaylov, S.; Lyubimov, E.; Ni, H.; Freedman, J.; Leytin, V. Mitochondrial Inner Membrane Depolarization as a Marker of Platelet Apoptosis: Disclosure of Nonapoptotic Membrane Depolarization. Clin. Appl. Thromb. 2017, 23, 139-147. [CrossRef]

84. Lauber, K.; Bohn, E.; Kröber, S.M.; Xiao, Y.J.; Blumenthal, S.G.; Lindemann, R.K.; Marini, P.; Wiedig, C.; Zobywalski, A.; Baksh, S.; et al. Apoptotic cells induce migration of phagocytes via caspase-3-mediated release of a lipid attraction signal. Cell 2003, 113, 717-730. [CrossRef]

85. El Kebir, D.; Filep, J.G. Modulation of neutrophil apoptosis and the resolution of inflammation through $\beta 2$ integrins. Front. Immunol. 2013, 4, 60. [CrossRef]

86. Fox, S.; Leitch, A.E.; Duffin, R.; Haslett, C.; Rossi, A.G. Neutrophil apoptosis: Relevance to the innate immune response and inflammatory disease. J. Innate Immun. 2010, 2, 216-227. [CrossRef] [PubMed]

87. Walsh, J.G.; Cullen, S.P.; Sheridan, C.; Lüthi, A.U.; Gerner, C.; Martin, S.J. Executioner caspase-3 and caspase-7 are functionally distinct proteases. Proc. Natl. Acad. Sci. USA 2008, 105, 12815-12819. [CrossRef]

88. Elmore, S. Apoptosis: A Review of Programmed Cell Death. Toxicol. Pathol. 2007, 35, 495-516. [CrossRef] [PubMed]

89. Faleiro, L.; Lazebnik, Y. Caspases Disrupt the Nuclear-Cytoplasmic Barrier. J. Cell Biol. 2000, 151, 951-959. [CrossRef]

90. McComb, S.; Chan, P.K.; Guinot, A.; Hartmannsdottir, H.; Jenni, S.; Dobay, M.P.; Bourquin, J.P.; Bornhauser, B.C. Efficient apoptosis requires feedback amplification of upstream apoptotic signals by effector caspase-3 or -7. Sci. Adv. 2019, 5, eaau9433. [CrossRef]

91. Lecoeur, H. Nuclear apoptosis detection by flow cytometry: Influence of endogenous endonucleases. Exp. Cell Res. 2002, 277, 1-14. [CrossRef]

92. Simons, M.P.; Nauseef, W.M.; Griffith, T.S.; Apicella, M.A. Neisseria gonorrhoeae delays the onset of apoptosis in polymorphonuclear leukocytes. Cell. Microbiol. 2006, 8, 1780-1790. [CrossRef] [PubMed]

93. Prasad, C.V.; Nayak, V.L.; Ramakrishna, S.; Mallavadhani, U.V. Novel menadione hybrids: Synthesis, anticancer activity, and cell-based studies. Chem. Biol. Drug Des. 2018, 91, 220-233. [CrossRef]

94. Kågedal, K.; Johansson, A.C.; Johansson, U.; Heimlich, G.; Roberg, K.; Wang, N.S.; Jürgensmeier, J.M.; Ollinger, K. Lysosomal membrane permeabilization during apoptosis-involvement of Bax? Int. J. Exp. Path. 2005, 86, 309-321. [CrossRef]

95. Jung, S.; Jeong, H.; Yu, S.W. Autophagy as a decisive process for cell death. Exp. Mol. Med. 2020, 52, 921-930. [CrossRef] [PubMed]

96. Ouseph, M.M.; Huang, Y.; Banerjee, M.; Joshi, S.; MacDonald, L.; Zhong, Y.; Liu, H.; Li, X.; Xiang, B.; Zhang, G.; et al. Autophagy is induced upon platelet activation and is essential for hemostasis and thrombosis. Blood 2015, 126, 1224-1233. [CrossRef]

97. Feng, W.; Chang, C.; Luo, D.; Su, H.; Yu, S.; Hua, W.; Chen, Z.; Hu, H.; Liu, W. Dissection of autophagy in human platelets. Autophagy 2014, 10, 642-651. [CrossRef] [PubMed]

98. Skendros, P.; Mitroulis, I.; Ritis, K. Autophagy in neutrophils: From granulopoiesis to neutrophil extracellular traps. Front. Cell Dev. Biol. 2018, 6, 109. [CrossRef]

99. Vural, A.; Kehrl, J.H. Autophagy in Macrophages: Impacting Inflammation and Bacterial Infection. Scientifica 2014, 2014, 825463. [CrossRef]

100. Rodríguez-Vargas, J.M.; Oliver-Pozo, F.J.; Dantzer, F. PARP1 and poly(ADP-ribosyl)ation signaling during autophagy in response to nutrient deprivation. Oxid. Med. Cell. Longev. 2019, 2019, 2641712. [CrossRef] [PubMed]

101. Zaidieh, T.; Smith, J.R.; Ball, K.E.; An, Q. ROS as a novel indicator to predict anticancer drug efficacy. BMC Cancer 2019, 19, 1224 [CrossRef] [PubMed]

102. Lin, K.H.; Hsiao, G.; Shih, C.M.; Chou, D.S.; Sheu, J.R. Mechanisms of resveratrol-induced platelet apoptosis. Cardiovasc. Res. 2009, 83, 575-585. [CrossRef]

103. Leytin, V.; Gyulkhandanyan, A.V.; Freedman, J. Platelet Apoptosis Can Be Triggered Bypassing the Death Receptors. Clin. Appl. Thromb. Hemost. 2019, 25, 1076029619853641. [CrossRef] [PubMed]

104. Park, K.-S.; Lee, M.-G. Effects of unaccustomed downhill running on muscle damage, oxidative stress, and leukocyte apoptosis. J. Exerc. Nutr. Biochem. 2015, 19, 55-63. [CrossRef] [PubMed]

105. Nita, M.; Grzybowski, A. The Role of the Reactive Oxygen Species and Oxidative Stress in the Pathomechanism of the Age-Related Ocular Diseases and Other Pathologies of the Anterior and Posterior Eye Segments in Adults. Oxid. Med. Cell. Longev. 2016, 2016, 3164734. [CrossRef]

106. Dziedzic, A.; Morel, A.; Miller, E.; Bijak, M.; Sliwinski, T.; Synowiec, E.; Ceremuga, M.; Saluk-Bijak, J. Oxidative Damage of Blood Platelets Correlates with the Degree of Psychophysical Disability in Secondary Progressive Multiple Sclerosis. Oxid. Med. Cell. Longev. 2020, 2020, 2868014. [CrossRef] [PubMed] 
107. Lopes-Pires, M.E.; Ahmed, N.S.; Vara, D.; Gibbins, J.M.; Pula, G.; Pugh, N. Zinc regulates reactive oxygen species generation in platelets. Platelets 2021, 32, 368-377. [CrossRef]

108. Kosmachevskaya, O.V.; Novikova, N.N.; Topunov, A.F. Carbonyl Stress in Red Blood Cells and Hemoglobin. Antioxidants 2021, 10, 253. [CrossRef]

109. Matarrese, P.; Straface, E.; Pietraforte, D.; Gambardella, L.; Vona, R.; Maccaglia, A.; Minetti, M.; Malorni, W. Peroxynitrite induces senescence and apoptosis of red blood cells through the activation of aspartyl and cysteinyl proteases. FASEB J. 2005, 19, 1-27. [CrossRef]

110. Haag, F.; Janicova, A.; Xu, B.; Powerski, M.; Fachet, M.; Bundkirchen, K.; Neunaber, C.; Marzi, I.; Relja, B.; Sturm, R. Reduced phagocytosis, ROS production and enhanced apoptosis of leukocytes upon alcohol drinking in healthy volunteers. Eur. J. Trauma Emerg. Surg. 2021. [CrossRef]

111. Jacinto, T.A.; Meireles, G.S.; Dias, A.T.; Aires, R.; Porto, M.L.; Gava, A.L.; Vasquez, E.C.; Pereira, T.M.C.; Campagnaro, B.P.; Meyrelles, S.S. Increased ROS production and DNA damage in monocytes are biomarkers of aging and atherosclerosis. Biol. Res. 2018, 51, 33. [CrossRef]

112. Heredia, A.; Davis, C.; Amoroso, A.; Dominique, J.K.; Le, N.; Klingebiel, E.; Reardon, E.; Zella, D.; Redfield, R.R. Induction of G 1 cycle arrest in T lymphocytes results in increased extracellular levels of-chemokines: A strategy to inhibit R5 HIV-1. Proc. Natl. Acad. Sci. USA 2003, 100, 4179-4184. [CrossRef]

113. Gérard, C.; Goldbeter, A. The balance between cell cycle arrest and cell proliferation: Control by the extracellular matrix and by contact inhibition. Interface Focus 2014, 4, 20130075. [CrossRef]

114. Nikbakht, M.; Pakbin, B.; Brujeni, G.N. Evaluation of a new lymphocyte proliferation assay based on cyclic voltammetry; an alternative method. Sci. Rep. 2019, 9, 4503. [CrossRef]

115. Uchihara, Y.; Tago, K.; Taguchi, H.; Narukawa, Y.; Kiuchi, F.; Tamura, H.; Funakoshi-Tago, M. Taxodione induces apoptosis in BCR-ABL-positive cells through ROS generation. Biochem. Pharmacol. 2018, 154, 357-372. [CrossRef] [PubMed]

116. Wang, W.; Niu, S.; Qiao, L.; Wei, F.; Yin, J.; Wang, S.; Ouyang, Y.; Chen, D. Usnea Acid as Multidrug Resistance (MDR) Reversing Agent against Human Chronic Myelogenous Leukemia K562/ADR Cells via an ROS Dependent Apoptosis. Biomed. Res. Int. 2019, 2019, 8727935. [CrossRef] [PubMed]

117. Damiano, S.; Muscariello, E.; La Rosa, G.; Di Maro, M.; Mondola, P.; Santillo, M. Dual role of reactive oxygen species in muscle function: Can antioxidant dietary supplements counteract age-related sarcopenia? Int. J. Mol. Sci. 2019, 20, 3815. [CrossRef] [PubMed]

118. Araújo, A.A.S.; De Melo, M.G.D.; Rabelo, T.K.; Nunes, P.S.; Santos, S.L.; Serafini, M.R.; Santos, M.R.V.; Quintans, L.J.; Gelain, D.P. Review of the biological properties and toxicity of usnic acid. Nat. Prod. Res. 2015, 29, 2167-2180. [CrossRef] [PubMed]

119. Favreau, J.T.; Ryu, M.L.; Braunstein, G.; Orshansky, G.; Park, S.S.; Coody, G.L.; Love, L.A.; Fong, T.L. Severe hepatotoxicity associated with the dietary supplement LipoKinetix. Ann. Intern. Med. 2002, 136, 590-595. [CrossRef]

120. Hsu, L.M.; Huang, Y.S.; Chang, F.Y.; Lee, S.D. “Fat burner" herb, usnic acid, induced acute hepatitis in a family. J. Gastroenterol. Hepatol. 2005, 20, 1138-1139. [CrossRef]

121. Yellapu, R.K.; Mittal, V.; Grewal, P.; Fiel, M.; Schiano, T. Acute liver failure caused by "fat burners" and dietary supplements: A case report and literature review. Can. J. Gastroenterol. 2011, 25, 157-160.

122. Sanchez, W.; Maple, J.T.; Burgart, L.J.; Kamath, P.S. Severe hepatotoxicity associated with use of a dietary supplement containing usnic acid. Mayo Clin. Proc. 2006, 81, 541-544. [CrossRef] [PubMed]

123. Fujimoto, K.; Kishino, H.; Hashimoto, K.; Watanabe, K.; Yamoto, T.; Mori, K. Biochemical profiles of rat primary cultured hepatocytes following treatment with rotenone, FCCP, or (+)-usnic acid. J. Toxicol. Sci. 2020, 45, 339-347. [CrossRef] [PubMed]

124. Han, D.; Matsumaru, K.; Rettori, D.; Kaplowitz, N. Usnic acid-induced necrosis of cultured mouse hepatocytes: Inhibition of mitochondrial function and oxidative stress. Biochem. Pharmacol. 2004, 67, 439-451. [CrossRef]

125. Bessadottir, M.; Egilsson, M.; Einarsdottir, E.; Magnusdottir, I.H.; Ogmundsdottir, M.H.; Omarsdottir, S.; Ogmundsdottir, H.M. Proton-Shuttling Lichen Compound Usnic Acid Affects Mitochondrial and Lysosomal Function in Cancer Cells. PLoS ONE 2012, 7, e51296. [CrossRef] [PubMed]

126. Chen, C.; Zhao, D.; Fang, S.; Chen, Q.; Cheng, B.; Fang, X.; Shu, Q. TRIM22-Mediated Apoptosis is Associated with Bak Oligomerization in Monocytes. Sci. Rep. 2017, 7, 39961. [CrossRef] [PubMed]

127. Bačkorová, M.; Bačkor, M.; Mikeš, J.; Jendželovský, R.; Fedoročko, P. Variable responses of different human cancer cells to the lichen compounds parietin, atranorin, usnic acid and gyrophoric acid. Toxicol. Vitr. 2011, 25, 37-44. [CrossRef] [PubMed]

128. Ozturk, S.; Erkisa, M.; Oran, S.; Ulukaya, E.; Celikler, S.; Ari, F. Lichens exerts an anti-proliferative effect on human breast and lung cancer cells through induction of apoptosis. Drug Chem. Toxicol. 2021, 44, 259-267. [CrossRef]

129. Disoma, C.; Erkisa, M.; Oran, S.; Aloglou, I.; Ulkaya, E.; Ari, F. Usnea filipendula Induces Apoptosis in Human Colon Cancer Cell Lines. Indian J. Pharm. Sci. 2018, 80, 1078-1085. [CrossRef]

130. Koparal, A.T.; Tüylü, B.A.; Türk, H. In vitro cytotoxic activities of (+)-usnic acid and (-)-usnic acid on V79, A549, and human lymphocyte cells and their non-genotoxicity on human lymphocytes. Nat. Prod. Res. 2006, 20, 1300-1307. [CrossRef]

131. Geng, X.; Zhang, X.; Zhou, B.; Zhang, C.; Tu, J.; Chen, X.; Wang, J.; Gao, H.; Qin, G.; Pan, W. Usnic acid induces cycle arrest, apoptosis, and autophagy in gastric cancer cells in vitro and in vivo. Med. Sci. Monit. 2018, 24, 556-566. [CrossRef] 